
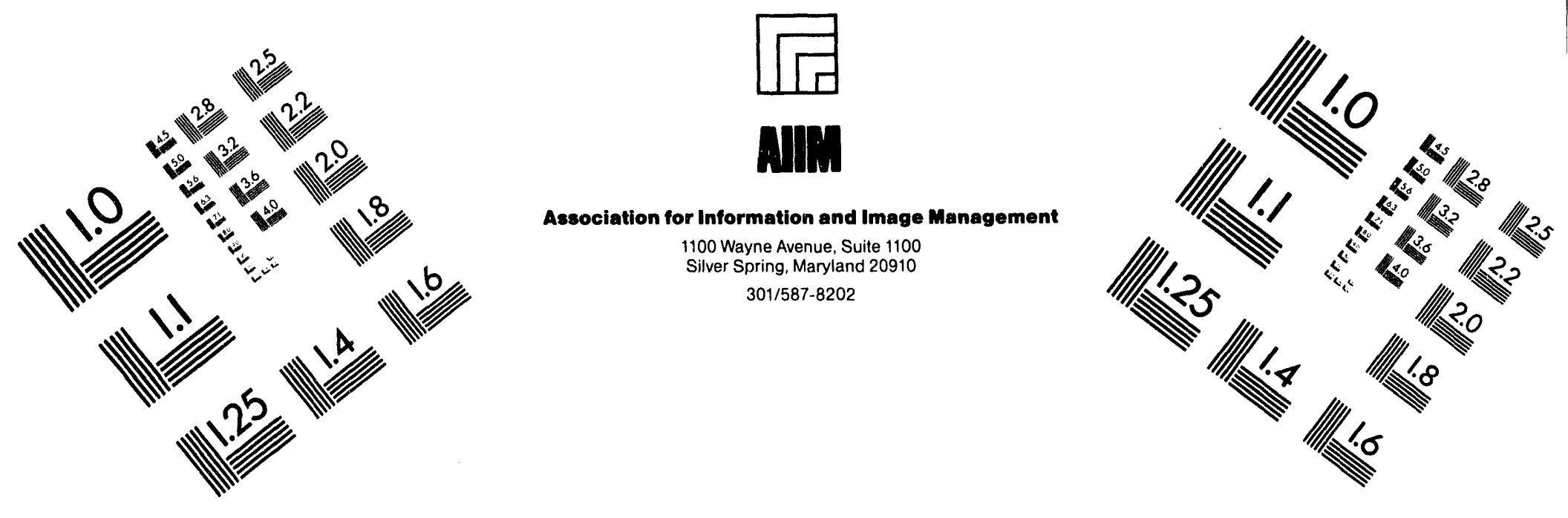

\title{
Centimeter
}

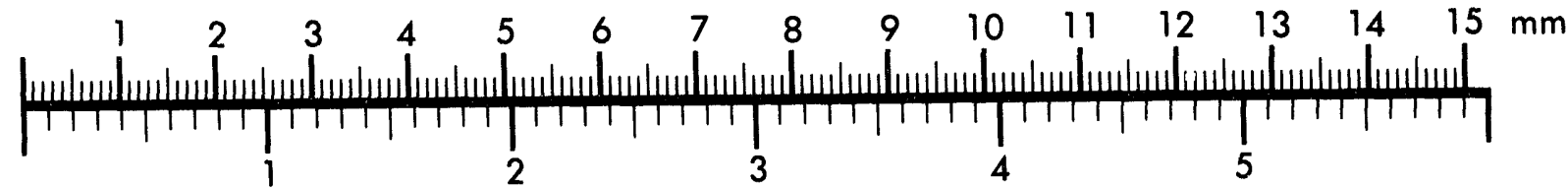
Inches
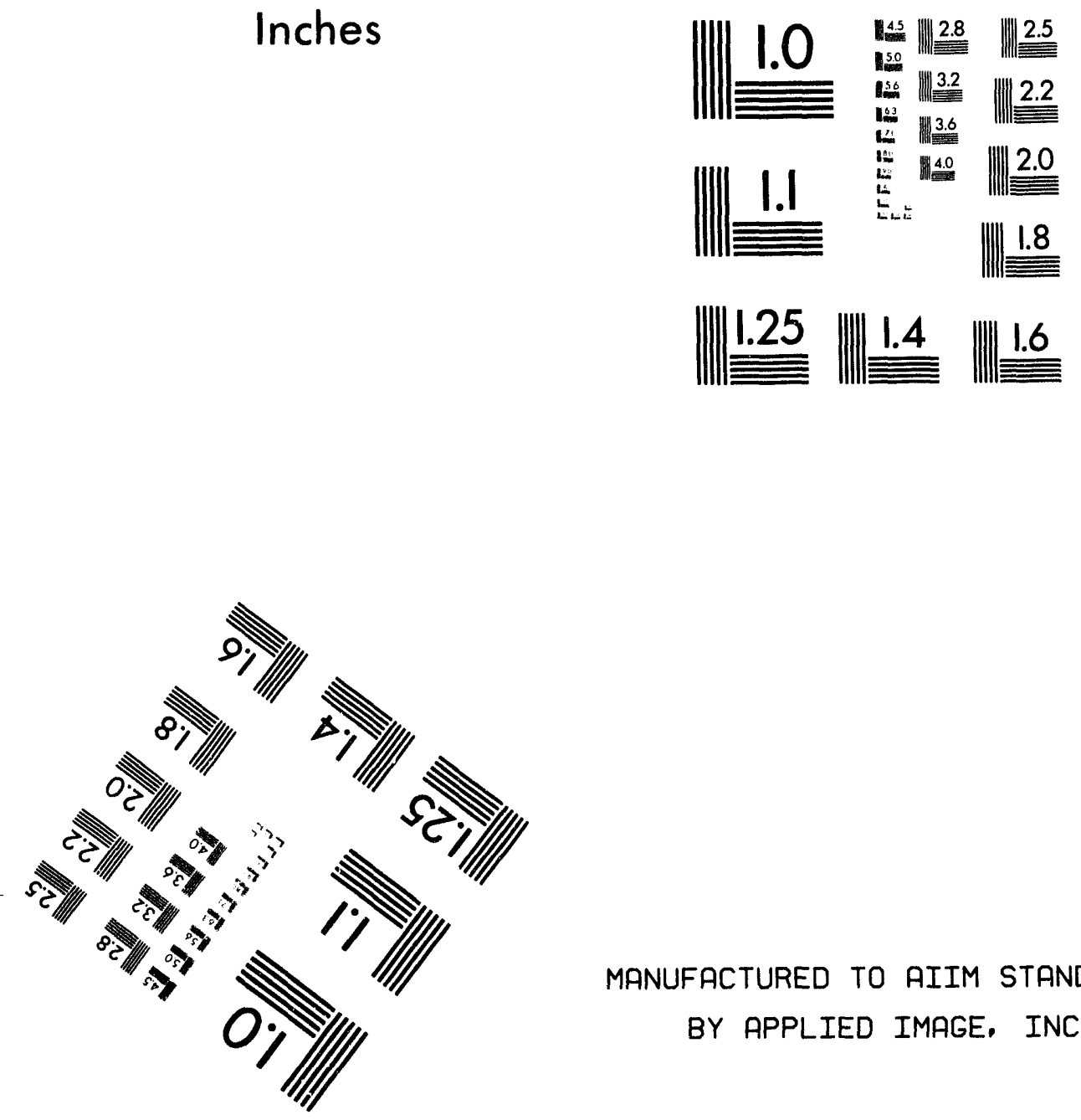

MANUFACTURED TO AIIM STANDARDS BY APPLIED IMAGE, INC.

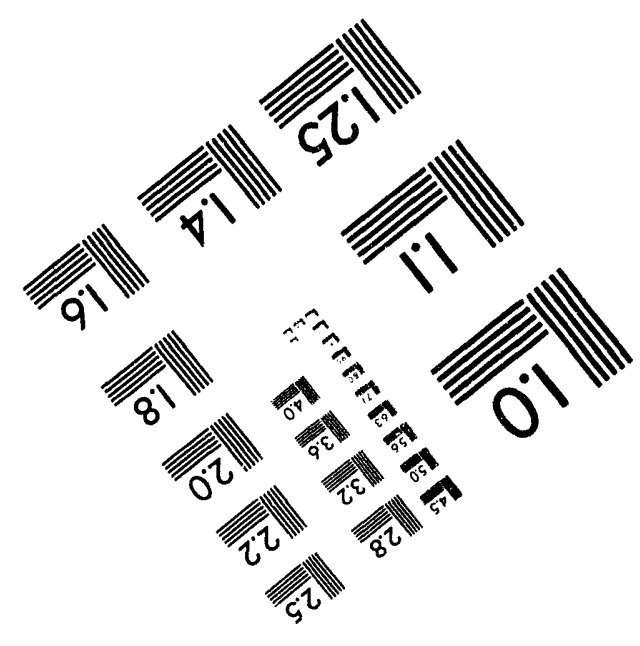



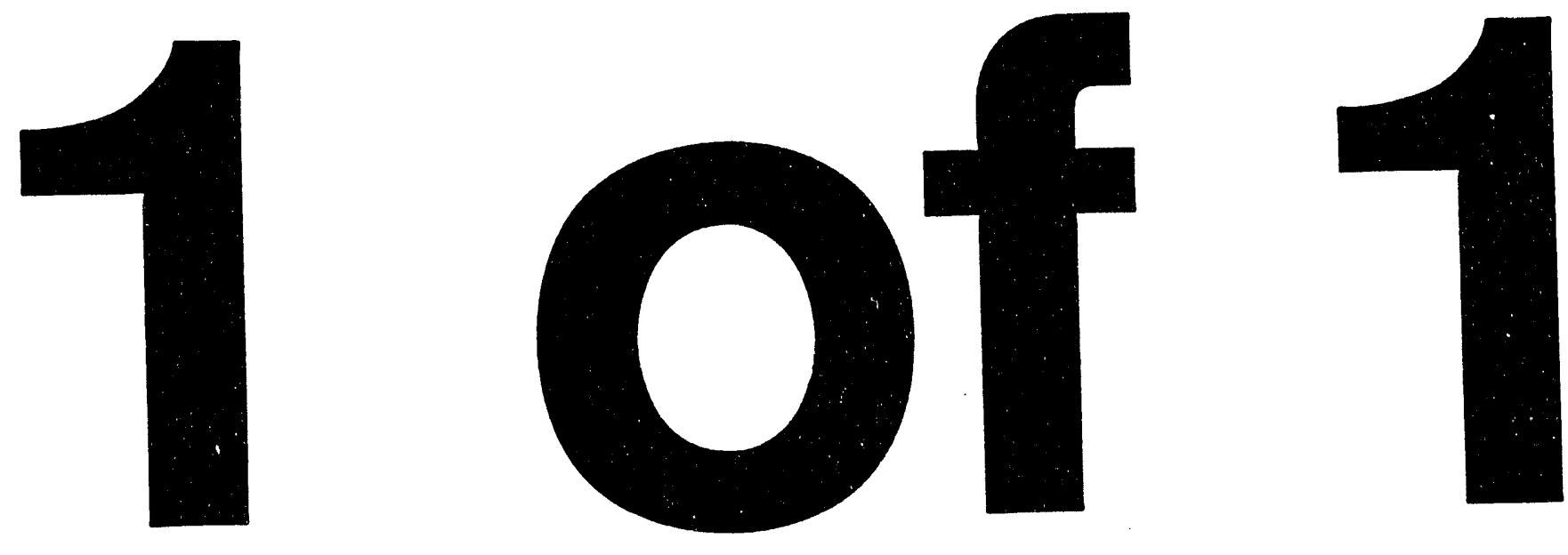


\section{UMTRA PROJECT WATER SAMPLING AND ANALYSIS PLAN Old and New Rifle, Colorado}

July 1994

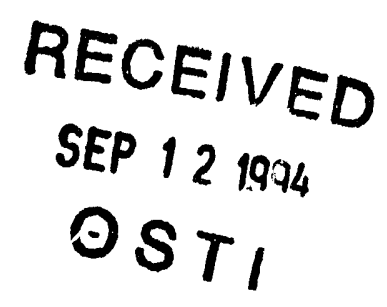




\section{INTENDED FOR PUBLIC RELEASE}

This report has been reproduced from the best available copy. Available in paper copy and microfiche.

Number of pages in this report: 52

DOE and DOE contractors can obtain copies of this report from:

Office of Scientific and Technical Information

P.O. Box 62

Oak Ridge, TN 37831

(615) 576-8401

This report is publicly available from:

National Technical Information Service

Department of Commerce

5285 Port Royal Road

Springfield, VA 22161

(703) $487-4650$ 


\section{UMTRA PROJECT \\ WATER SAMPLING AND ANALYSIS PLAN OLD AND NEW RIFLE, COLORADO}

July 1994

\section{DISCLAIMER}

This report was prepared as an account of work sponsored by an agency of the United States Government. Neither the United States Government nor any agency thereof, nor any of their employees, makes any warranty, express or implied, or assumes any legal liability or responsibility for the accuracy, completeness, or usefulness of any information, apparatus, product, or process disclosed, or represents that its use would not infringe privately owned rights. Reference herein to any specific commercial product, process, or service by trade name, trademark, manufacturer, or otherwise does not necessarily constitute or imply its endorsement, recommendation, or favoring by the United States Government or any agency thereof. The views and opinions of authors expressed herein do not necessarily state or reflect those of the United States Government or any agency thereof.

\section{Prepared for \\ U.S. Department of Energy UMTRA Project Office Albuquerque, New Mexico \\ Prepared by Jacobs Engineering Group Inc. Albuquerque, New Mexico}




\section{EXECUTIVE SUMMARY}

Surface remedial action at the Rifle, Colorado, Uranium Mill Tailings Remedial Action (UMTRA) Project site began in the spring of 1992. Results of water sampling at the Old and New Rifle processing sites for recent years indicate that ground water contamination occurs in the shallow unconfined alluvial aquifer (the uppermost aquifer) and less extensively in the underlying Wasatch Formation.

Uranium and sulfate continue to exceed background ground water concentrations and/or maximum concentration limits at and downgradient from the former processing sites. These constituents provide the best indication of changes in contaminant distribution.

Contamination in the uppermost (alluvial) aquifer at New Rifle extends a minimum of approximately 5000 feet (ft) (1524 meters [m]) downgradient. At Old Rifle, the extent of contamination in the alluvial aquifer is much less (a minimum of approximately $1000 \mathrm{ft}$ [305 m]), partially due to differences in hydrologic regime. For example, the Old Rifle site lies in a relatively narrow alluvial floodplain; the New Rifle site lies in a broad floodplain.

Data gathering for the Rifle baseline risk assessment is under way. The purpose of this effort is to determine with greater precision the background ground water quality and extent of ground water contamination at the processing sites.

Historical surface water quality indicates that the Colorado River has not been affected by uranium processing activities.

No compliance monitoring of the Estes Gulch disposal cell has been proposed, because ground water in the underlying Wasatch Formation is limited use (Class III) ground water and because the disposal cell is hydrogeologically isolated from the uppermost aquifer.

Water sampling activities planned for calendar year 1994 consist of the following:

- Semiannual sampling of 7 U.S. Department of Energy (DOE) alluvial wells at Old Rifle and 10 DOE alluvial wells at New Rifle. The analytical results will be used to continue characterizing downgradient hydrogeochemical trends occurring as a result of source term (tailings) removal.

- Annual sampling of four DOE Wasatch Formation wells at Old Rifle and eight DOE Wasatch Formation wells at New Rifle. The DOE plans to sample Wasatch Formation wells annually instead of semiannually because average linear ground water flow velocities (and thus contaminant migration rates) in the Wasatch Formation are significantly less than in the alluvial aquifer.

- Semiannual sampling of one private well (RFN-0428) located downgradient from the New Rifle processing site. This well will be sampled to monitor water quality changes due to suspected migration of tailings seepage. 
- Annual sampling of the 12 remaining domestic well/spring locations in the vicinity of the Rifle sites.

- Sampling of four surface water locations near the former processing sites. RFO-0572 will be sampled annually from the pond located directly downgradient of the Old Rifle processing site. Surface water locations RFO-0570 and RFO-0573, located upgradient from the Old Rifle site, will be sampled semiannually from One-Mile Pond and from a seep northeast of the pond. RFN-0575 will be sampled semiannually from the Roaring Fork gravel pit located downgradient from the New Rifle processing site.

The selected monitoring locations provide a representative distribution of sampling points to characterize water quality and ground water flow conditions in the vicinity of the Rifle processing sites. The list of analytes has been modified over time and currently reflects constituents related to uranium processing activities. 
TABLE OF CONTENTS

Section

Page

EXECUTIVE SUMMARY $\ldots \ldots \ldots \ldots \ldots \ldots \ldots \ldots \ldots \ldots \ldots \ldots \ldots \ldots$

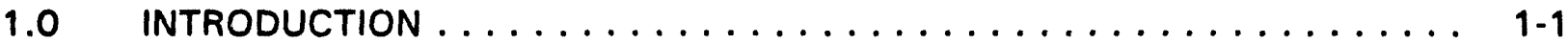

$1.1 \quad$ Purpose .............................. 1-1

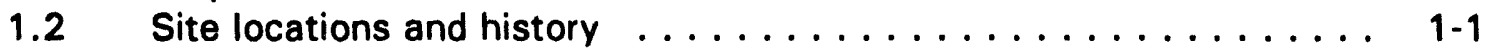

1.3 Water use ......................... 1-3

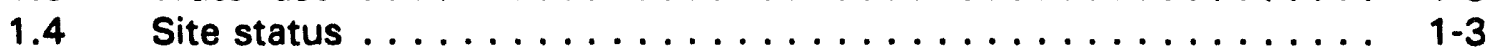

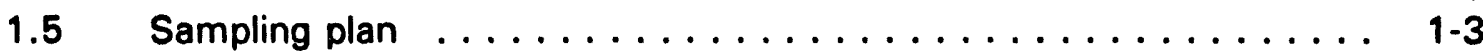

2.0 OLD AND NEW RIFLE PROCESSING SITES $\ldots \ldots \ldots \ldots \ldots \ldots \ldots \ldots \ldots \ldots$

2.1 Site conceptual model . . . . . . . . . . . . . . . . . . 2-1

2.1.1 Physiographic setting . . . . . . . . . . . 2-1

2.1.2 Geology ................... 2-1

2.1.3 Hydrology ................... 2-1

2.1 .4 Water quality ................. $2-4$

2.2 Data collection objectives .................. 2-22

2.2.1 Regulatory requirements . . . . . . . . . . 2-22

2.2.2 Compliance monitoring . . . . . . . . . . 2-26

2.2.3 Site characterization ...............2-26

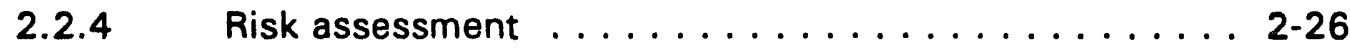

2.3 Water sampling plan ..................... 2-26

2.3.1 Sampling locations . . . . . . . . . . . . 2-27

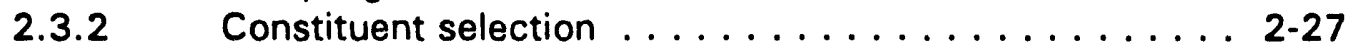

2.3.3 Sampling frequency ................ 2-31

2.3.4 Data interpretation ................. 2-31

2.3.5 Anomalous data evaluation ............ 2-32

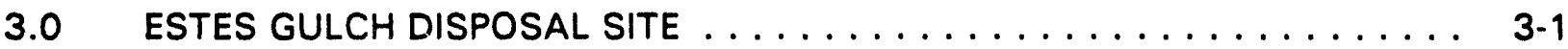

$3.1 \quad$ Site conceptual model . . . . . . . . . . . . . . . . 3-1

3.1.1 Physiographic setting ............... 3 -1

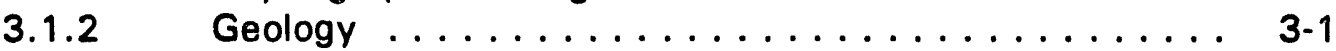

3.1.3 Hydrology ....................

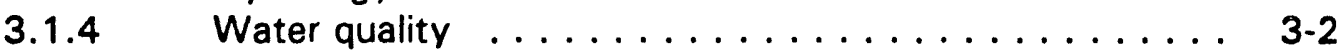

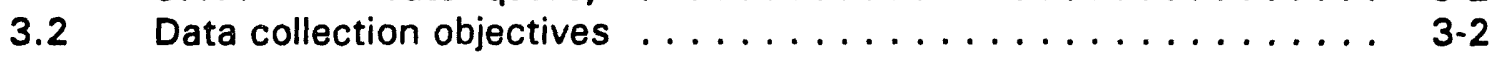

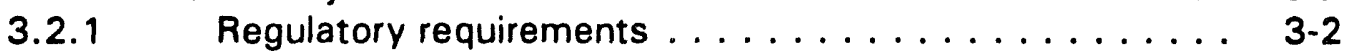

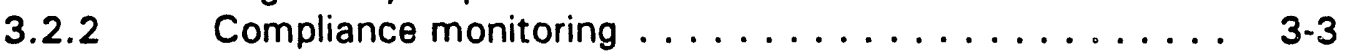

3.3 Water sampling plan ..................... 3.3

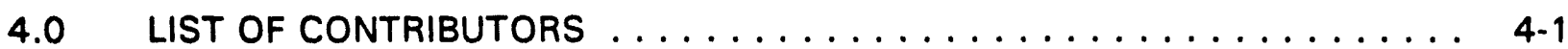

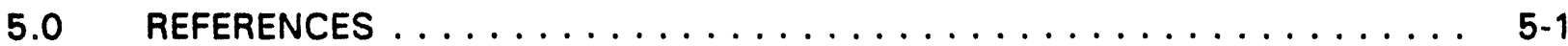




\section{LIST OF FIGURES}

Figure

1.1 Locations of the Rifle, Colorado, processing sites and the Estes Gulch

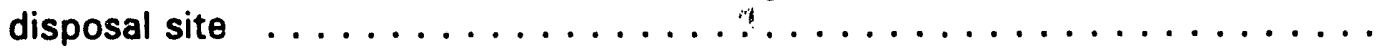

2.1 Alluvial aquifer and Wasatch Formation monitor well location map, Old Rifle, Colorado, site . . . . . . . . . . . . . . . . . . . . .

2.2 Alluvial aquifer and Wasatch Formation monitor well location map, New Rifle, Colorado, site . . . . . . . . . . . . . . . . . . . . . .

2.3 Old Rifle processing site sulfate concentration map for the alluvial aquifer, Colorado (March 1993) ... . . . . . . . . . . . . . . . . . . 2.7

2.4 Old Rifle processing site uranium concentration map for the alluvial aquifer, Colorado (March 1993) ...................... 2-8

2.5 New Rifle processing site sulfate concentration map for the alluvial aquifer, Colorado (March 1993) . . . . . . . . . . . . . . . . . . 2-9

2.6 New Rifle processing site uranium concentration map for the alluvial aquifer, Colorado (March 1993) . . . . . . . . . . . . . . . . . . . 2-10

2.7 Sulfate concentration trends in the alluvial aquifer, Old Rifle, Colorado, processing site .......................... 2-12

2.8 Uranium concentration trends in the alluvial aquifer, Old Rifle, Colorado, processing site . . . . . . . . . . . . . . . . . . . 2-13

2.9 Sulfate concentration trends in the alluvial aquifer, New Rifle, Colorado, processing site . . . . . . . . . . . . . . . . . . . 2-14

2.10 Uranium concentration trends in the alluvial aquifer, New Rifle, Colorado, processing site ......................... 2-15

2.11 Domestic well/spring sampling locations in the vicinity of the Rifle, Colorado, sites . . . . . . . . . . . . . . . . . . . . . . . 2-19

2.12 Sulfate concentration trends in domestic wells in the vicinity of the New Rifle, Colorado, processing site . . . . . . . . . . . . . 2-21

2.13 Total uranium concentration trends in domestic wells in the vicinity of the New Rifle, Colorado, processing site . . . . . . . . . . . . . 2-23

2.14 Total sulfate concentration trends in downgradient domestic well RFN-0428, New Rifle, Colorado, processing site . . . . . . . . . . . . 2-24

2.15 Total uranium concentration trends in downgradient domestic well RFN-0428, New Rifle, Colorado, processing site . . . . . . . . . . . . 


\section{LIST OF TABLES}

Table

Page

2.1 Summary of analytical resuits for selected parameters that typify alluvial background and downgradient ground water quality in the vicinity of the Old and New Rifle, Colorado, sites.

2.2 Summary of analytical results for selected parameters that typify background and downgradient Wasatch Formation ground water quality in the vicinity of the Old and New Rifle, Colorado, sites . . . . . . . . . . . . 2-16

2.3 Description of and rationale for recommended sampling locations, Old Rifle, Colorado, site . . . . . . . . . . . . . . . . . . . . . . 2-28

2.4 Description of and rationale for recommended sampling locations, New Rifle, Colorado, site . . . . . . . . . . . . . . . . . . . . . . . . . . 2-29 


\section{LIST OF ACRONYMS AND ABBREVIATIONS}

\section{Acronym Definition}

$\begin{array}{ll}\text { ASER } & \text { annual site environmental report } \\ \mathrm{cm} / \mathrm{s} & \text { centimeters per second } \\ \text { DCO } & \text { data collection objective } \\ \text { DOE } & \text { U.S. Department of Energy } \\ \text { DQO } & \text { data quality objective } \\ \text { EPA } & \text { U.S. Environmental Protection Agency } \\ \mathrm{ft} & \text { foot } \\ \mathrm{km} & \text { kilometer } \\ \mathrm{m} & \text { meter } \\ \mathrm{MCL} & \text { maximum concentration limit } \\ \mathrm{mg} / \mathrm{L} & \text { milligrams per liter } \\ \mathrm{mi} & \text { mile } \\ \text { pCi/L } & \text { picocuries per liter } \\ \text { QA } & \text { quality assurance } \\ \text { QAIP } & \text { quality assurance implementation plan } \\ \text { QC } & \text { quality control } \\ \text { SOP } & \text { standard operating procedure } \\ \text { TDS } & \text { total dissolved solids } \\ \text { TOC } & \text { total organic carbon } \\ \text { UMTRA } & \text { Uranium Mill Tailings Remedial Action } \\ \text { WSAP } & \text { water sampling and analysis plan }\end{array}$




\subsection{INTRODUCTION}

\section{1}

\section{PURPOSE}

This water sampling and analysis plan (WSAP) provides the regulatory and technical basis for ground water and surface water sampling at the U.S. Department of Energy (DOE) Uranium Mill Tailings Remedial Action (UMTRA) Project sites at Rifle, Colorado. Rifle sites include both former processing sites (Old Rifle [RFO01]) and New Rifle [RFNO1]). Also included is the Estes Gulch disposal site (RFNO8). The WSAP identifies and justifies ground water and surface water sampling locations, selection of analytical parameters, and sampling frequencies at the sites. The ground water and surface water data are used for site characterization and risk assessment.

Ground water and surface water monitoring activities are based on the U.S. Environmental Protection Agency (EPA) regulations in 40 CFR Part 192 (1994) and proposed EPA ground water quality standards of 1.987 (52 FR 36000 (1987)), UMTRA Project standard operating procedures (SOP) (JEG, n.d.), the Technical Approach Document (DOE, 1989), and the most effective technical approach for the site.

This version of the WSAP includes a summary and results of past water sampling activities and the plan for water sampling activities for calendar year 1994.

\subsection{SITE LOCATIONS AND HISTORY}

The Rifle, Colorado, UMTRA Project sites consist of two separate tailings sites adjacent to the city of Rifle in Garfield County, Colorado, and the Estes Gulch disposal site north of Rifle. Figure 1.1 shows the locations of all three sites in relation to the city of Rifle.

The Colorado River is immediately south of both tailings sites. The eastern site, known as the Old Rifle site, is approximately 0.3 mile (mi) $(0.48$ kilometer [km]) from the center of Rifle in Township 6 South, Range 93 West, Section 15 NW 1/4 and Section 16 NE 1/4. The western site, known as New Rifle, is approximately $2 \mathrm{mi}(3.2 \mathrm{~km})$ from the center of Rifle in Township 6 South, Range 93 West, Section 18.

The Estes Gulch disposal site is $6 \mathrm{mi}(9.6 \mathrm{~km})$ north of the Old Rifle site and approximately 9 road mi $(14.4 \mathrm{~km})$ north of the New Rifle site. The Estes Gulch disposal site is in Township 5 South, Range 93 West, Section 14.

The uranium mill at the Old Rifle site was owned and operated by the Union Carbide Corporation (Union Carbide) from 1924 to 1932 and from 1942 to 1958. From 1932 to 1942 , the Union Carbide mill was idle for economic reasons. The mill produced vanadium during both operating periods and uranium during the latter period. 

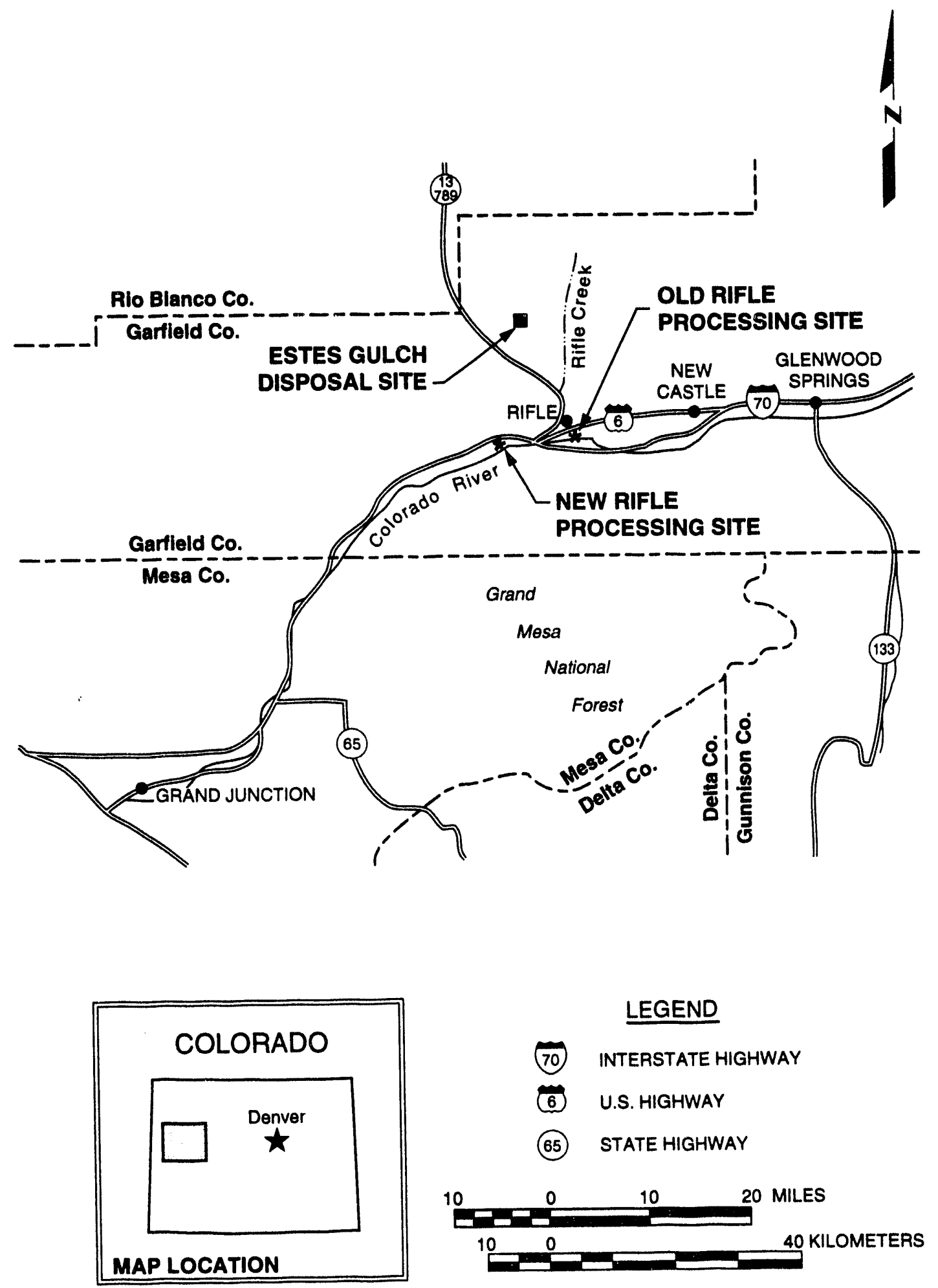

FIGURE 1.1

LOCATIONS OF THE RIFLE, COLORADO, PROCESSING SITES AND THE ESTES GULCH DISPOSAL SITE 
The New Rifle mill replaced the Old Rifle mill in 1958; it was also owned and operated by Union Carbide. The mill was constructed as part of a complex that included the upgraders at Slick Rock, Colorado, and Green River, Utah. Ore and the upgrader products from Slick Rock and Green River were shipped to the mill by truck and railroad. From 1958 to 1973, the mill produced uranium and vanadium. From 1973 to 1984 , a portion of the mill was used to produce vanadium; this operation involved processing vanadium-bearing solutions and did not produce tailings (FBDU, 1977).

\subsection{WATER USE}

The Colorado River is and has been the primary source of domestic water in the Rifle area. The city of Rifle obtains its water for municipal use from the Colorado River approximately $0.5 \mathrm{mi}(0.8 \mathrm{~km})$ upgradient from the Old Rifle tailings site. About a dozen domestic-use wells near the former Rifle processing sites are being monitored. These wells are located outside the Rifle city limits. According to well owners, water from these wells is not being used for drinking.

Because of its poor quality, ground water directly beneath the Estes Gulch disposal site in the Wasatch Formation is not likely to be used in the future. Ground water in formations of the Mesaverde Group (which contains the Williams Fork Formation [uppermost aquifer]) is too deep to be used costeffertively for domestic or stock watering purposes.

\subsection{SITE STATUS}

Surface remedial action activities at the fifle sites began in 1992; these activities are scheduled to be completed in 1995. The remedial action consists of stabilizing tailings and other processing-related debris in the Estes Gulch disposal cell. Other processing-related debris includes demolition debris from the former mill processing yard, windblown material, waterborne contamination, and vicinity property contamination.

A baseline risk assessment is also under way for both former processing sites. The baseline risk assessment is scheduled to be completed in 1995.

\subsection{SAMPLING PLAN}

The current Old and New Rifle sampling plan calls for water samples to be collected from selected DOE monitor well locations and domestic locations and for surface water/sediment samples to be collected from locations that are needed for site characterization and risk assessment. The monitor well locations allow ground water quality and/or ground water flow conditions near the sites to be characterized. The list of analytes currently contains constituents related to uranium processing activities and natural uranium mineralization.

The only remaining 1994 water quality sampling round is scheduled for August. 


\subsection{OLD AND NEW RIFLE PROCESSING SITES}

\subsection{SITE CONCEPTUAL MODEL}

\subsubsection{Phrsiegraphic setting}

The Old and New Rifle former processing sites are on the southeastern flank of the asymmetric Piceance Creek Basin, a structural basin containing relatively horizontal sedimentary and volcanic rocks. The Colorado River valley is incised into the Wasatch Formation. It is bordered on the north by the Book Cliffs and the Grand Hogback monocline and on the south by the Roan Cliffs.

\subsubsection{Geology}

The Old and New Rifle tailings sites rest on the Colorado River floodplain alluvium, which is made up of silts, sands, gravels, and cobbles. The alluvium thickness ranges from approximately 10 to 30 feet (ft) ( 3 to 9 meters [m]) at each site.

The underlying Wasatch Formation near the former Rifle processing sites consists of a series of interbedded shales and lenticular sandstone units dipping 5 to 10 degrees to the west-southwest. The formation contains the Shire, Molina, and Atwell Gulch Members. The upper Shire Member is $1600 \mathrm{ft}$ $(488 \mathrm{~m})$ thick near Rifle and consists of variegated claystones, siltstones, and some lenticular sandstones. The middle Molina Member, $500 \mathrm{ft}(152 \mathrm{~m})$ thick, consists primarily of sandstone with thin, interbedded claystones and siltstones. The lower Atwell Gulch Member, approximately $600 \mathrm{ft}(183 \mathrm{~m})$ thick, contains a series of shales and sandstones with thin, discontinuous interbeds of lignite and carboniferous shale.

\subsubsection{Hydrology}

Both the Old and New Rifle processing sites are underlain by two water-bearing hydrogeologic units: a shallow unconfined aquifer in the alluvium lining the Colorado River and a semiconfined aquifer in the Wasatch Formation bedrock beneath the alluvium.

The alluvium is recharged by precipitation, regional ground water flow from upgradient water-bearing formations, and return irrigation flow. Seasonal fluctuations in the Colorado River also influence flow in the alluvium and Wasatch Formation.

Figure 2.1 shows well locations for the alluvial aquifer and Wasatch Formation at the former Old Rifle processing site. Figure 2.2 shows well locations for both hydrogeologic units at the New Rifle processing site. In general, ground water flow in the alluvium and Wasatch Formation at the Rifle sites is toward the southwest. During periods of high river stage, flow near the Colorado River 


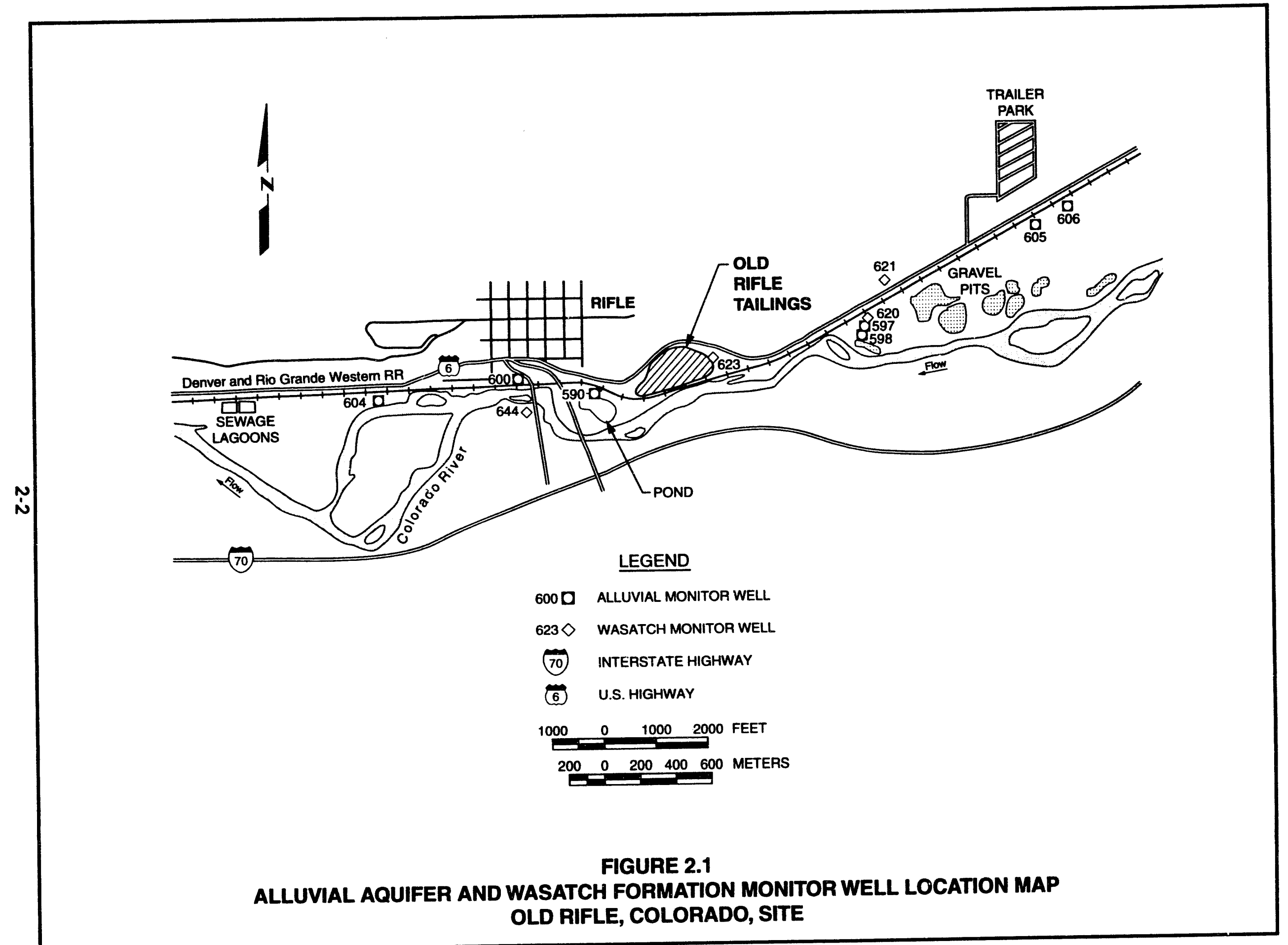




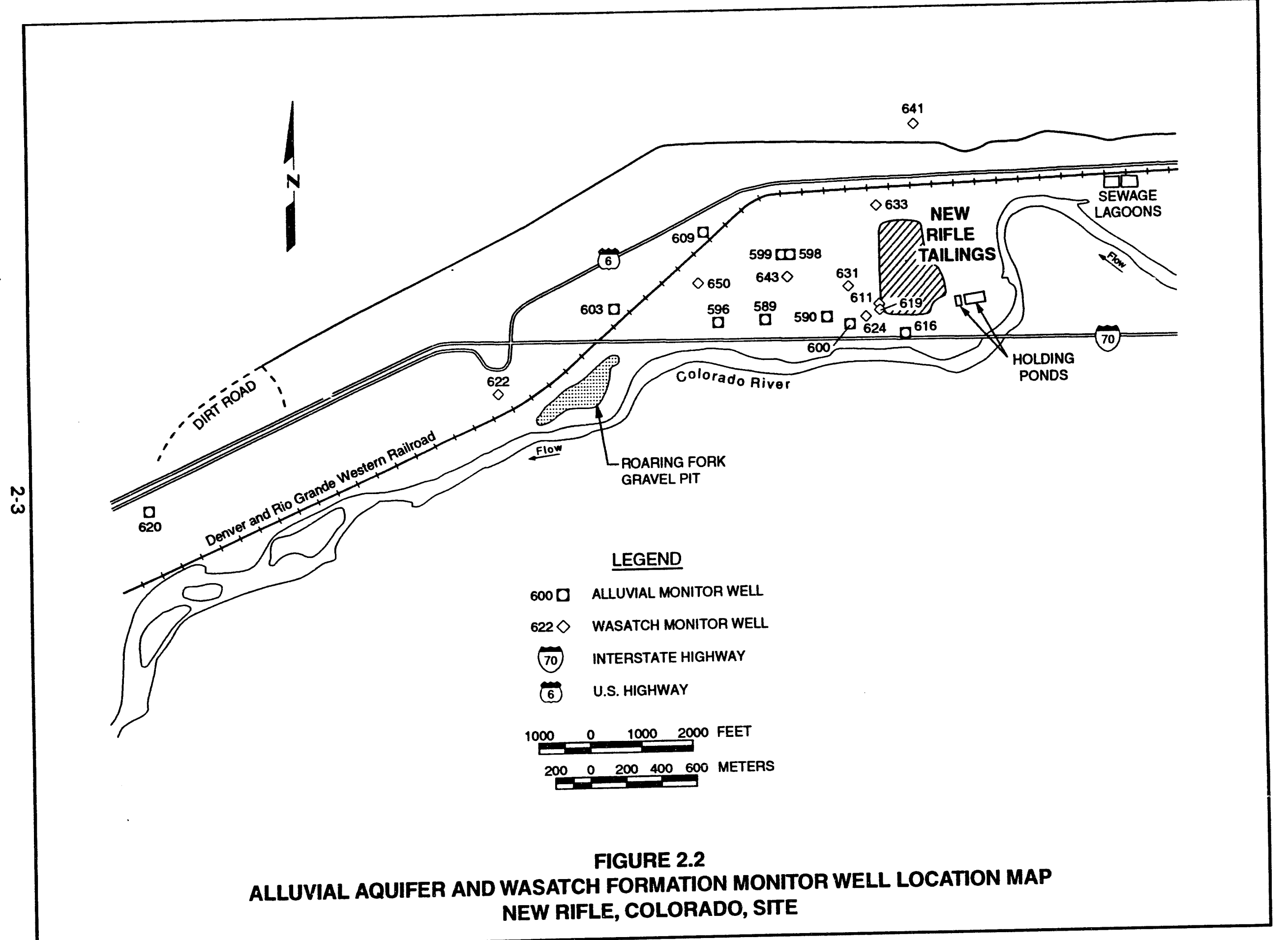


probably parallels the river. During periods of low river stage, alluvial ground water probably discharges to the Colorado River. Ground water levels generally fluctuate between 2 to $5 \mathrm{ft}(0.61$ to $1.5 \mathrm{~m})$ annually.

Limited test data indicate that hydraulic conductivities at the Old Rifle site average $200 \mathrm{ft}$ per day $\left(7.0 \times 10^{-2}\right.$ centimeters per second $\left.[\mathrm{cm} / \mathrm{s}]\right)$ in the alluvium and $0.02 \mathrm{ft}$ per day $\left(7.0 \times 10^{-6} \mathrm{~cm} / \mathrm{s}\right)$ in the Wasatch Formation. Average linear ground water velocities are in the range of $840 \mathrm{ft}(256 \mathrm{~m})$ per year in the alluvium and $0.3 \mathrm{ft}(0.09 \mathrm{~m})$ per year in the Wasatch Formation.

Limited test data indicate that hydraulic conductivities at the New Rifle site average $70 \mathrm{ft}$ per day $\left(2.5 \times 10^{-2} \mathrm{~cm} / \mathrm{s}\right)$ in the alluvium and $0.09 \mathrm{ft}$ per day $\left(3.2 \times 10^{-5} \mathrm{~cm} / \mathrm{s}\right)$ in the Wasatch Formation. Average linear ground water velocities are in the range of $280 \mathrm{ft}(85 \mathrm{~m})$ per year in the alluvium and $3.0 \mathrm{ft}$ $(0.9 \mathrm{~m})$ per year in the Wasatch Formation.

The main channel of the Colorado River at the Old Rifle site is within $75 \mathrm{ft}$ $(23 \mathrm{~m})$ of the tailings but is separated from them by a railroad embankment. At New Rifle, the floodplain is much broader. Near New Rifle, the main channel of the Colorado River has been artificially channeled northward by blocking alternative river channels upstream of the site. The Colorado River is about $1000 \mathrm{ft}(305 \mathrm{~m})$ east and $600 \mathrm{ft}(183 \mathrm{~m})$ south of the tailings pile.

In addition to the Colorado River, a number of other surface water features are present near the sites. These surface water features include a pond downgradient from the Old Rifle site, the Roaring Fork gravel pit downgradient from the New Rifle site, and a number of additional, unnamed ditches, sewage lagoons, and ponds (Figures 2.1 and 2.2).

\subsubsection{Water quality}

Background water quality is defined as the quality of water that would be present if uranium processing activities had not occurred at the site.

Background water quality was characterized by sampling monitor wells and surface waters located hydraulically upgradient from the processing sites and analyzing the water for appropriate constituents. Generally, the list of analytes includes the proposed EPA hazardous constituents and other chemical constituents recognized as indicators of uranium processing activities.

Baseline ground water quality is defined as the representative water quality in a monitor well that has been influenced by uranium processing activities IDOE, 1989). Ground water at the Rifle processing sites has been contaminated by acidic tailings leachate. The leachate contains concentrations of arsenic, barium, cadmium, molybdenum, nitrate, selenium, and uranium and activities of net gross alpha and radium-226 and -228 combined that have exceeded maximum concentration limits (MCL). 


\section{Alluvial aquifer}

Table 2.1 summarizes analytical results for selected parameters in alluvial background and downgradient ground water in the vicinity of both the Old and New Rifle sites. At the Old Rifle site, upgradient DOE monitor well RFO-0598 has been selected as a monitor well that is representative of alluvial background ground water (Figure 2.1). Wells used to typify downgradient ground water quality include RFO-0590, located approximately $1000 \mathrm{ft}(305 \mathrm{~m})$ downgradient from the tailings pile, and RFO-0600, located approximately $2000 \mathrm{ft}(610 \mathrm{~m})$ downgradient.

Wells used to typify downgradient ground water quality at New Rifle include well RFN-0596, located about $2500 \mathrm{ft}(762 \mathrm{~m})$ southwest of the New Rifle tailings pile, and well RFN-0603, located approximately $5000 \mathrm{ft}(1524 \mathrm{~m})$ west of the tailings.

The $\mathrm{pH}$ of the background ground waters in the vicinity of the Rifle sites has historically ranged from 6.95 to 7.30. The relatively low values of total organic carbon (TOC) suggest that significantly reducing conditions do not occur in background ground water. The total dissolved solids (TDS) in the background ground water samples historically range from approximately 1260 to 3210 milligrams per liter (mg/L). The background alkalinity (as $\mathrm{mg} / \mathrm{L} \mathrm{CaCo3}$ ) ranges between 424 and 559. The dominant anionic species in the background water is sulfate, which ranges from 476 to $1470 \mathrm{mg} / \mathrm{L}$. The dominant cations in background ground water are sodium and calcium. The EPA MCLs have been exceeded by background alluvial concentrations of chromium, molybdenum, selenium, and uranium and activities of net gross alpha at various times since sampling was initiated at the processing sites.

Once leachate is introduced to the more alkaline downgradient ground water typical of the Rifle processing sites, certain parameters, including uranium and sulfate, behave chemically conservatively (more mobile than other parameters). Uranium and sulfate serve as excellent tracers of the extent of contamination at the Rifle sites.

Figures 2.3 through 2.6 show the distribution of sulfate and uranium in the alluvial aquifer downgradient of the Old and New Rifle tailings piles. The figures indicate that contamination caused by the New Rifle pile has migrated significantly farther than contamination caused by the Old Rifle pile. The significant difference in the extent of contamination at the two sites is largely due to the narrowing of the floodplain directly downgradient of the Old Rifle site. Downgradient of Old Rifle, an outcrop of Wasatch bedrock slows contaminant migration and forces the contaminants toward the Colorado River before they have a chance to move significantly downgradient. 
Table 2.1 Summary of analytical results for selected parameters that typify alluvial background and downgradient ground water quality in the vicinity of the Old and New Rifle, Colorado, sites ${ }^{a}$

\begin{tabular}{|c|c|c|c|c|c|c|}
\hline \multirow[b]{3}{*}{ Parameter } & \multirow{3}{*}{$\begin{array}{l}\text { Background } \\
\text { RF0-0598 }\end{array}$} & \multirow[b]{3}{*}{ MCL } & \multicolumn{4}{|c|}{ Downgradient } \\
\hline & & & \multicolumn{2}{|c|}{ Old Rifle } & \multicolumn{2}{|c|}{ New Rifle } \\
\hline & & & RFO-0590 & RFO.0600 & RFN-0596 & RFN-0603 \\
\hline Alkalinity & 486 & & 411 & 754 & 671 & 585 \\
\hline pH & $6.95 \mathrm{SU}$ & & $7.01 \mathrm{su}$ & $7.12 \mathrm{SU}$ & $6.87 \mathrm{SU}$ & $6.88 \mathrm{SU}$ \\
\hline Sulfate & $488^{C}$ & & 1120 & 822 & 5390 & 979 \\
\hline TDS & $1270^{C}$ & & 2350 & 2140 & 9890 & 2010 \\
\hline TOC & 8 & & 8 & 10 & 11 & 6 \\
\hline Calcium & 222 & & 201 & 247 & 357 & 165 \\
\hline Chloride & $87^{C}$ & & 144 & 113 & 1090 & 86.49 \\
\hline Iron & 1.17 & & $<0.03$ & 9.14 & $<0.15$ & 0.21 \\
\hline Magnesium & 163 & & 127 & 134 & 115 & 85.9 \\
\hline Sodium & 236 & & 321 & 247 & 2180 & 385 \\
\hline Nitrate & $<0.10^{C}$ & 44.0 & 4.0 & $<1.0$ & 711 & $<1.0$ \\
\hline Molybdenum & $<0.01$ & 0.1 & 0.01 & $<0.01$ & 0.16 & 0.02 \\
\hline $\begin{array}{l}\text { Radium-226/ } \\
-228\end{array}$ & $0.80 \mathrm{pCi} / \mathrm{L}$ & $5 \mathrm{pCi} / \mathrm{L}$ & $0.20 \mathrm{pCi} / \mathrm{L}$ & $1.20 \mathrm{pCi} / \mathrm{L}$ & $0.80 \mathrm{pCi} / \mathrm{L}$ & $1.30 \mathrm{pCi} / \mathrm{L}$ \\
\hline Selenium & $<0.005$ & 0.01 & 0.072 & $<0.005$ & $<0.05$ & $<0.005$ \\
\hline Uranium & 0.029 & 0.044 & 0.098 & 0.007 & 0.281 & 0.048 \\
\hline
\end{tabular}

aunless otherwise noted, concentrations are in milligrams per liter and results are from August 1993.

bSampled March 1993.

CSampled February 1992.

pCi/l - picocuries per liter.

SU - standard units. 


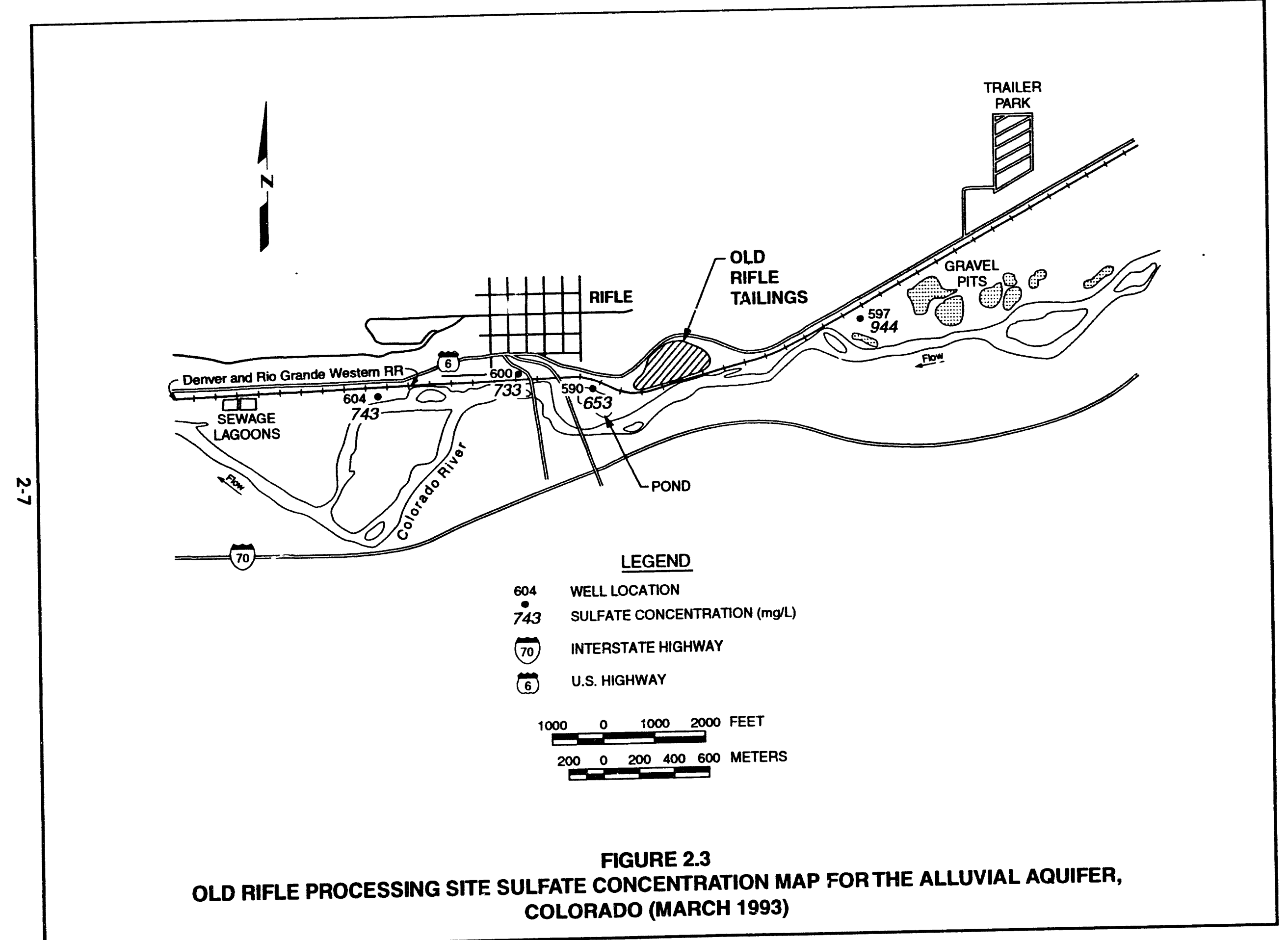




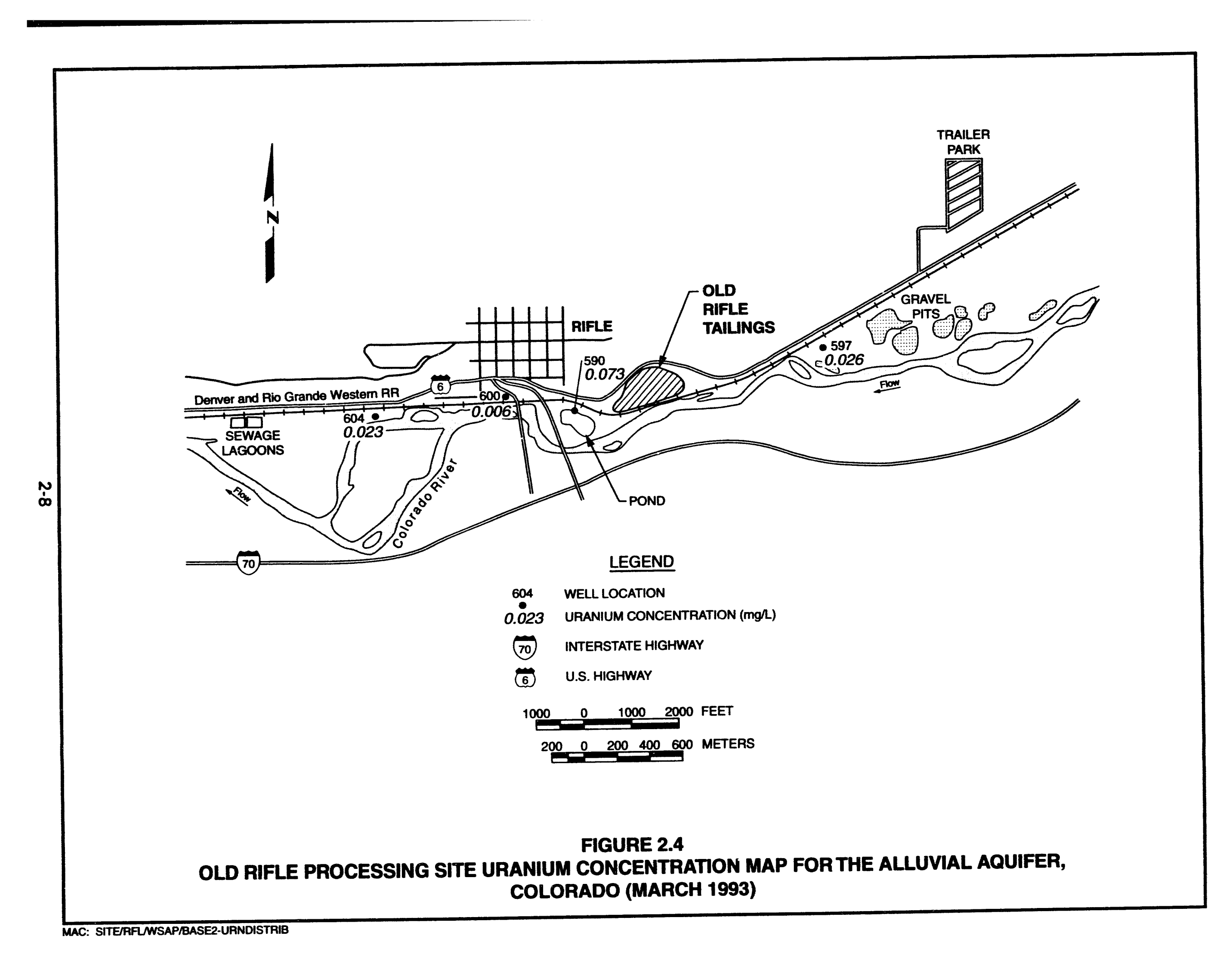




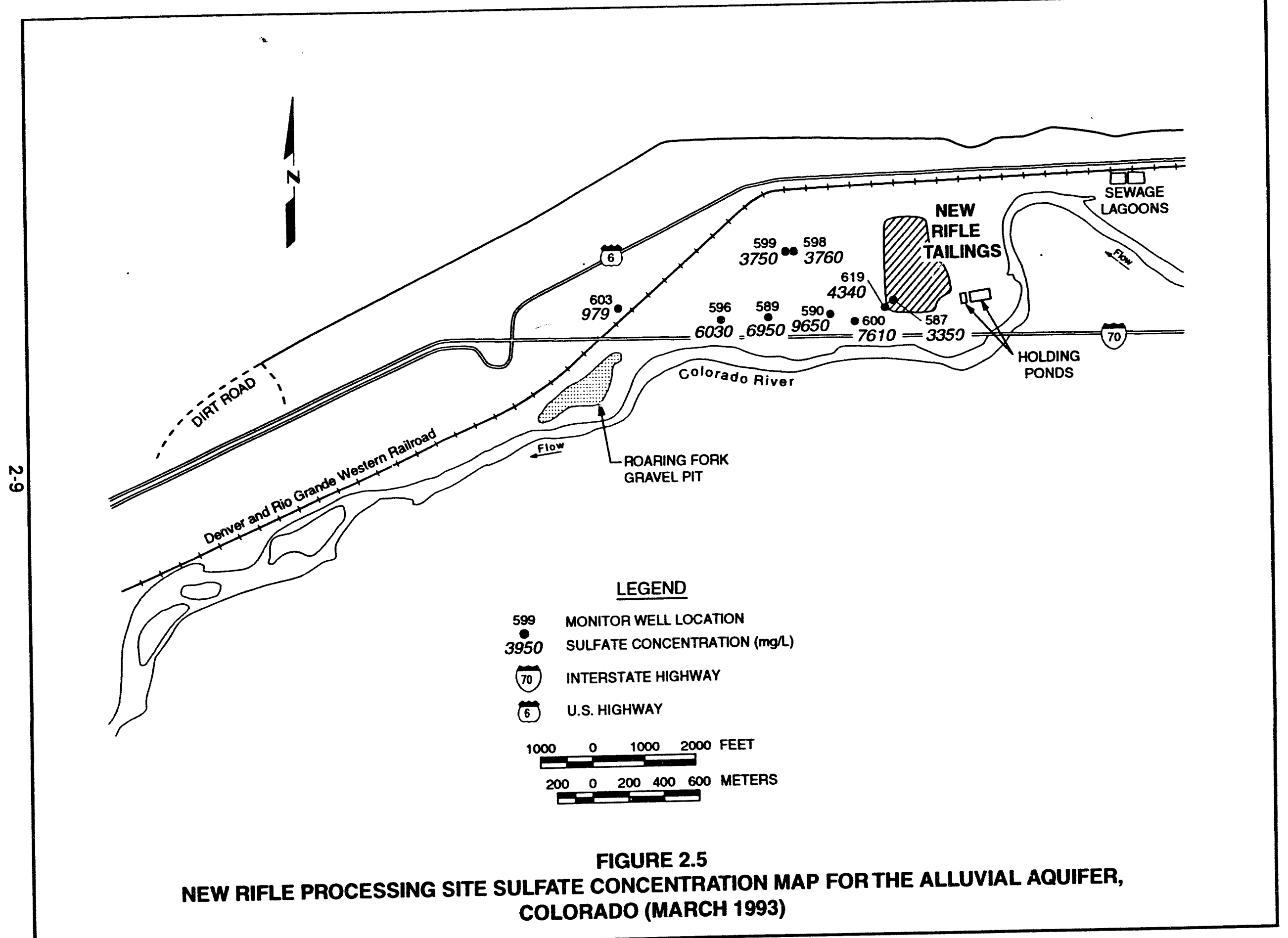




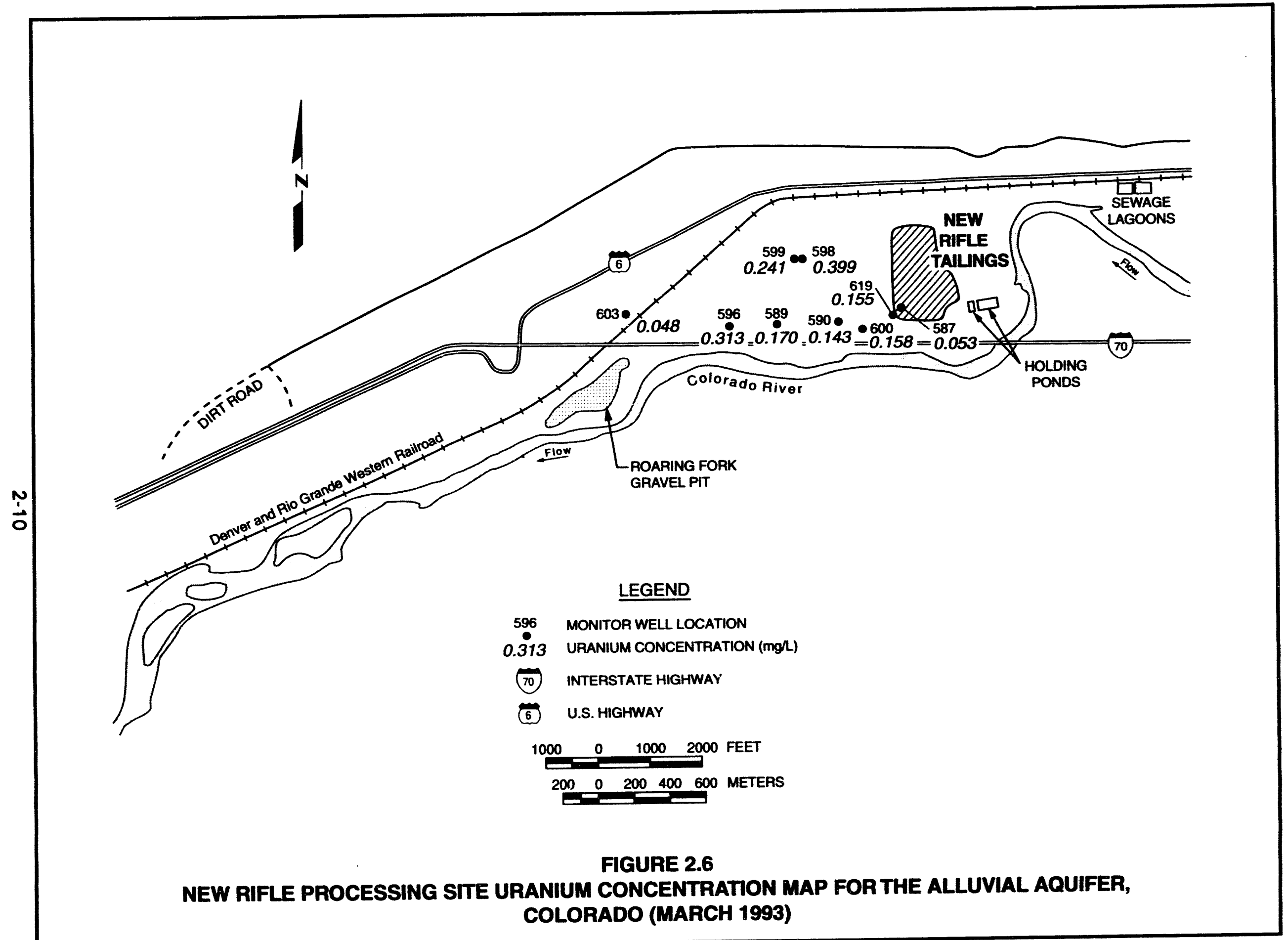


The trends for sulfate and uranium concentrations in the alluvium at Old and New Rifle over the past 4 years are shown in the figures 2.7 through 2.10. These graphs show ground water quality trends for sulfate and uranium for the typical background monitor well (RFO-0598), for monitor wells located in the contaminant plume, and for wells located farther downgradient.

Trends for Old Rifle show that background ground water is near the MCL for uranium (Figure 2.8). Data collected from monitor well RFO-0600, the well located farthest downgradient at Old Rifle, is probably showing lower concentrations of uranium because it is nearer to the Colorado River.

Trends for New Rifle (Figures 2.9 and 2.10) show that downgradient concentrations of indicator parameters are more concentrated than at Old Rifle. Monitor well RFN-0603 shows trends in concentration for sulfate and uranium that appear to be above background levels. Monitor well RFN-0603 is the DOE monitor well farthest downgradient from which analytical results are available.

\section{Wasatch Formation}

Table 2.2 summarizes anaiytical results for selected parameters in Wasatch Formation background and downgradient ground water in the vicinity of both Old and New Rifle. Upgradient DOE monitor well RFO-0621 has been selected as a monitor well that is in an area typical of Wasatch background ground water. Well RFO-0644 typifies downgradient (baseline) water quality in the Wasatch Formation at the Old Rifle site. Wells RFN-0611 and RFN-0631 typify downgradient water quality in the Wasatch Formation at the New Rifle site.

Background water quality in the Wasatch bedrock at the Rifle processing sites is a sodium-sulfate type with TDS historically ranging from approximately $119 \mathrm{C}$ to $2930 \mathrm{mg} / \mathrm{L}$ and $\mathrm{pH}$ ranging from 7.0 to approximately 8.0. Background concentrations of barium, molybdenum, selenium, uranium, and activities of net gross alpha and radium-226 and -228 combined have exceeded EPA MCLs in background Wasatch Formation ground water in the past.

Ground water quality in the Wasatch Formation at the Old Rifle site has been affected by uranium milling activities. The lateral extent of contamination is believed to be less than in the alluvium due to the lower hydraulic conductivity of the Wasatch Formation. It is difficult to determine the true lateral extent of contamination in the Wasatch Formation at the Old Rifle site due to the limited number of monitor wells completed in bedrock downgradient of tailings. TDS, sodium, and chloride concentrations detected in well RFO-0644 have consistently exceeded levels in background ground water. However, there is no clear indication of impact from tailings seepage (Table 2.2 and Figure 2.1).

The Wasatch Formation at New Riffe has also been affected by tailings seepage. The areal extent of contamination in the Wasatch Formation at New Rifle is also limited by the relatively low hydraulic conductivity of interbedded shales and sandstones (Table 2.2 and Figure 2.2). 


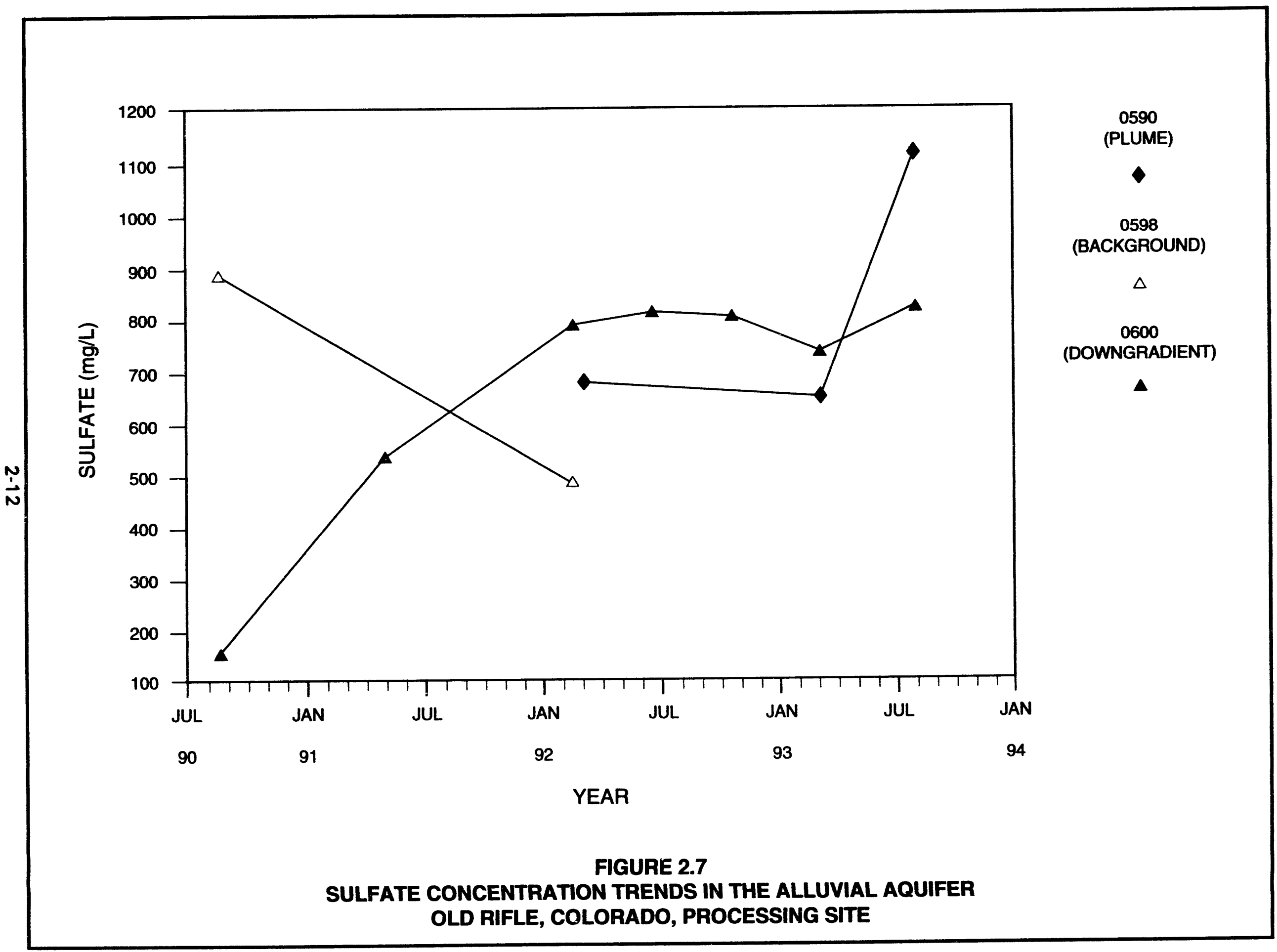

MAC: SITERFLWSAP/RFOALLUVSUL 


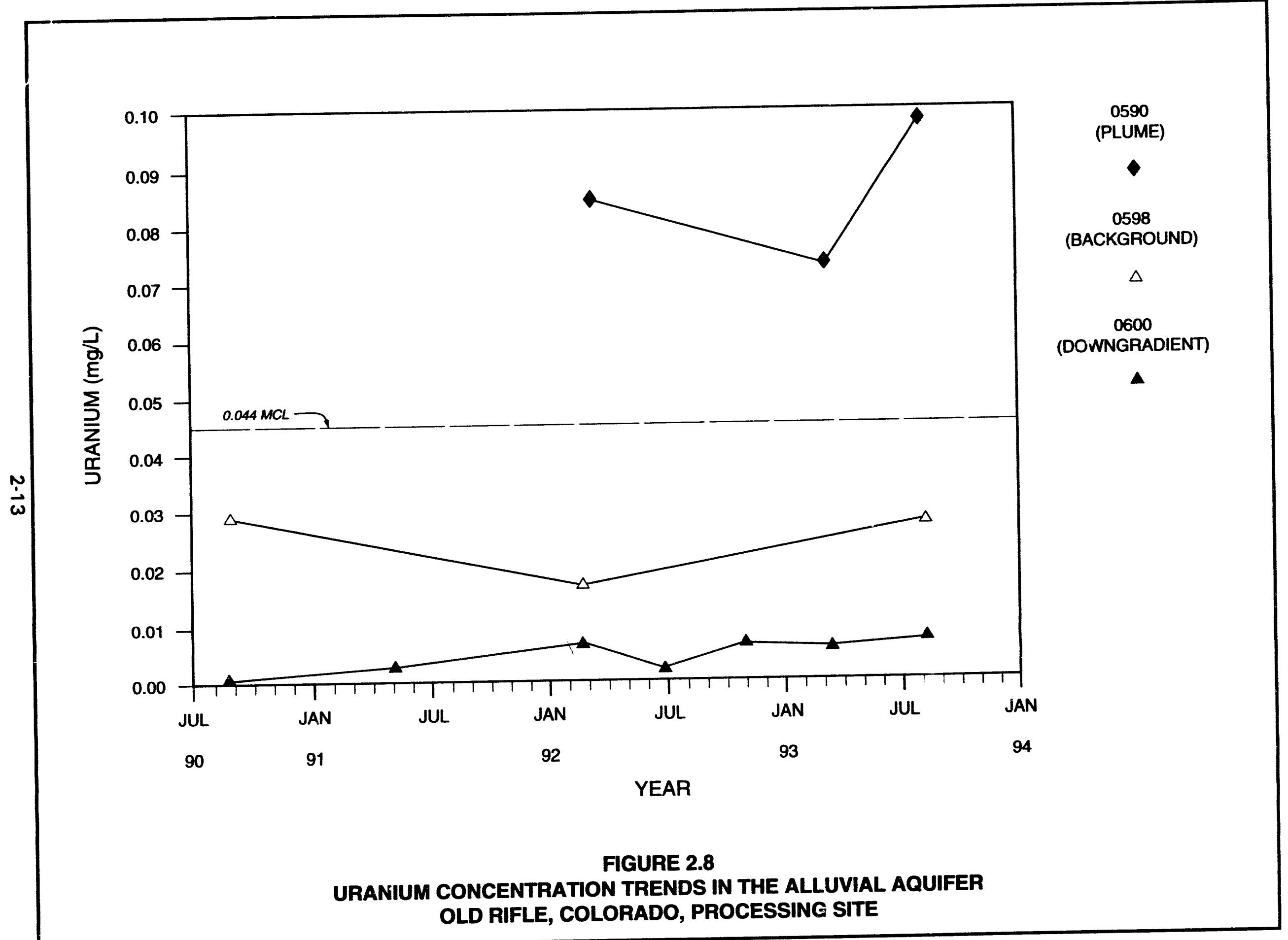




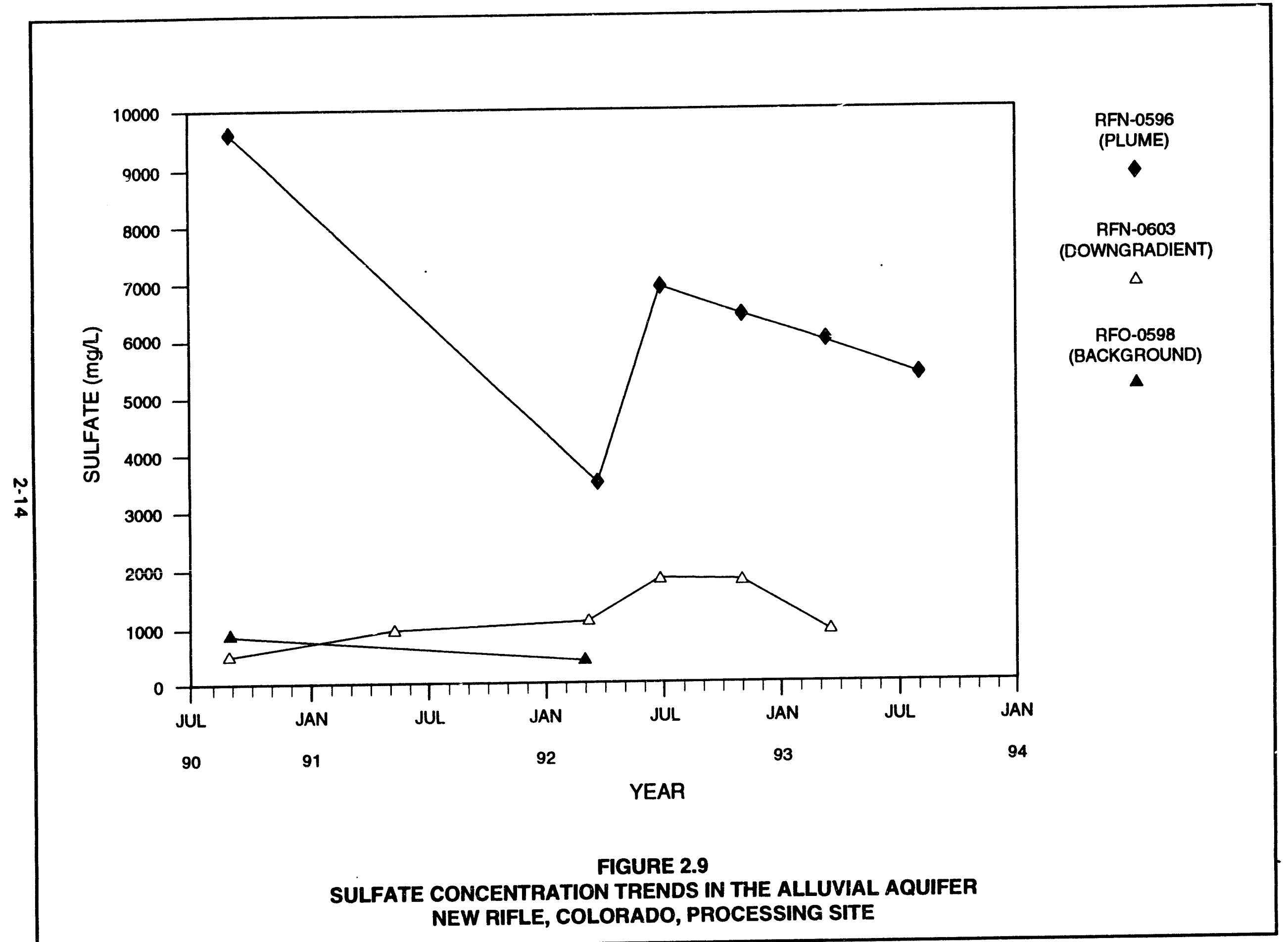




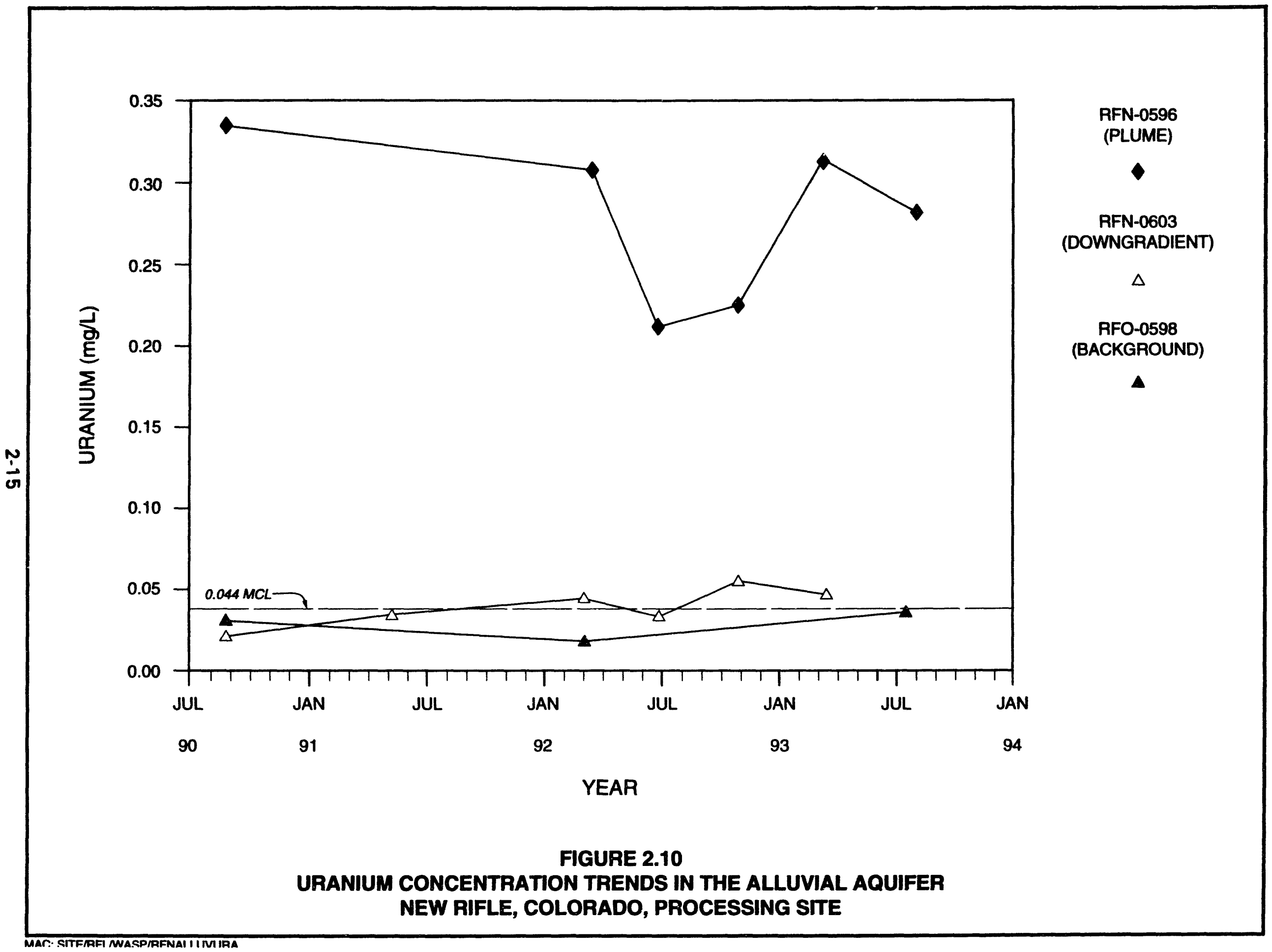


Table 2.2 Summary of analytical results for selected parameters wells that typify Wasatch Formation background and downgradient ground water quality in the vicinity of the Old and New Rifle, Colorado, sites ${ }^{\mathrm{a}}$

\begin{tabular}{|c|c|c|c|c|c|}
\hline \multirow[b]{3}{*}{ Parameter } & \multirow{3}{*}{$\begin{array}{l}\text { Background } \\
\text { RF0-0621 } \\
\end{array}$} & \multirow[b]{3}{*}{$\mathrm{MCL}$} & \multicolumn{3}{|c|}{ Downgradient } \\
\hline & & & \multirow{2}{*}{$\frac{\text { Old Rifle }}{\text { RFO-0644 }}$} & \multicolumn{2}{|c|}{ Now Rifle } \\
\hline & & & & RFN-0611 & RFN-0631 \\
\hline Alkalinity & 297 & & 115 & 634 & 323 \\
\hline pH & $8.09 \mathrm{su}$ & & $7.42 \mathrm{SU}$ & $7.01 \mathrm{su}$ & $7.65 \mathrm{SU}$ \\
\hline Sulfate & $26^{b}$ & & $<4$ & 7290 & 635 \\
\hline TDS & $2400^{b}$ & & 12,800 & 10,900 & 2310 \\
\hline TOC & $<1$ & & $"$ & 17 & 8 \\
\hline Calcium & 16.6 & & 328 & 385 & 63.0 \\
\hline Chloride & $1400^{b}$ & & 8,000 & 723 & 598 \\
\hline Iron & $<0.03$ & & 0.08 & 2.03 & 0.03 \\
\hline Magnesium & 4.4 & & 67.1 & 140 & 14.6 \\
\hline Sodium & 783 & & 3,330 & 2360 & 711 \\
\hline Barium & $0.25^{b}$ & 1.0 & 9.01 & $0.02^{b}$ & $<0.10^{c}$ \\
\hline Chromium & $<0.01$ & 0.05 & 0.03 & $<0.01^{b}$ & $<0.01^{c}$ \\
\hline Nitrate & $3.1^{b}$ & 44.0 & 4.4 & $<1$ & 1 \\
\hline Molybdenum & 0.14 & 0.1 & 0.03 & 1.20 & 0.03 \\
\hline $\begin{array}{l}\text { Radium-226/ } \\
-228\end{array}$ & $0.50 \mathrm{pCi} / \mathrm{L}$ & $5 \mathrm{pCi} / \mathrm{L}$ & $18.70 \mathrm{pCi} / \mathrm{L}$ & $3.38 \mathrm{pCi} / \mathrm{L}$ & $1.40 \mathrm{pCi} / \mathrm{L}$ \\
\hline Selenium & $<0.005$ & 0.01 & $<0.002$ & $<0.05$ & $<0.005$ \\
\hline Uranium & 0.002 & 0.044 & $<0.001$ & 0.121 & 0.001 \\
\hline
\end{tabular}

aUnless otherwise noted, concentrations are in milligrams per liter and results are from August 1993.

bSampled February 1992.

CSampled August 1990.

SU - standard units. 


\section{Surface water}

Contaminated alluvial ground water is believed to discharge, in part, to the Colorado River. However, surface water samples taken from the Colorado River indicate that the river has not been affected by uranium processing-related activities. Surface water quality data from other water bodies near the Old and New Rifle sites have been analyzed; these data suggest that only the Roaring Fork gravel pit, approximately $4800 \mathrm{ft}(1463 \mathrm{~m})$ downgradient of the New Rifle tailings pile, has been affected by tailings seepage (Figure 2.2).

The Roaring Fork gravel pit may be influencing migration of ground water contaminants. Lowering water levels in the pit, which causes ground water discharge to the pit, is altering local hydraulic gradients.

Data collected from the Roaring Fork gravel pit in August 1993 indicate that TDS, sulfate, and uranium concentrations are elevated above background levels. In August 1993, the TDS concentration was $9190 \mathrm{mg} / \mathrm{L}$, the sulfate concentration was $5600 \mathrm{mg} / \mathrm{L}$, and the uranium concentration was $0.365 \mathrm{mg} / \mathrm{L}$.

\section{Domestic water}

Twelve monitor wells and one private spring are currently being sampled in the vicinity of the Rifle sites. Current domestic sampling locations are shown in Figure 2.11. Analytical results from several of these wells have indicated levels of hazardous constituents that exceed MCLs. These hazardous constituents are uranium, nitrate, net gross alpha, and selenium.

Since most of the domestic wells are hydraulically upgradient from the tailings piles, the elevated hazardous constituents are probably due to upgradient, natural sources. The Rifle baseline risk assessment, which is currently being written, is partially aimed at gaining a better understanding of background ground water quality and the extent of contamination as it affects local domestic water users.

Water quality results from one domestic well (RFN-0428) may show an impact from migration of tailings seepage. RFN-0428 is approximately $2.5 \mathrm{mi}(4 \mathrm{~km})$ west of the New Rifle processing site. The other New Rifle vicinity domestic wells are all north (upgradient) of the processing site. Figure 2.12 shows concentrations of sulfate over time in domestic wells in the vicinity of the New Rifle site (including well RFN-0428). It indicates that the sulfate concentration in the vicinity of well RFN-0428 has significantly increased since 1991. Although Figure 2.12 indicates that a considerable range of sulfate (300 to $1100 \mathrm{mg} / \mathrm{L}$ ) is present in ground water sampled from domestic wells north of the New Rifle processing site, very little change in sulfate concentration occurs in individual wells. 


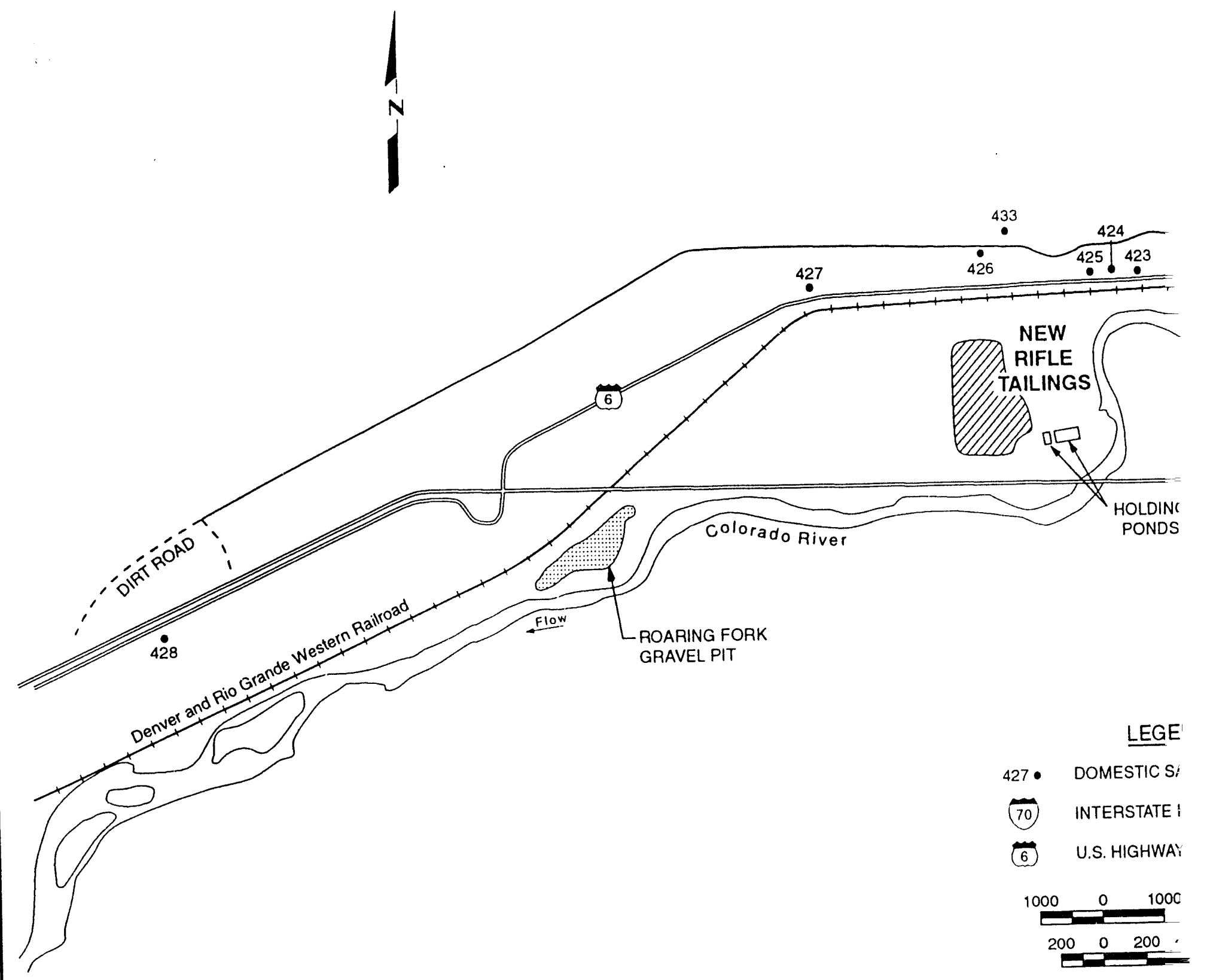




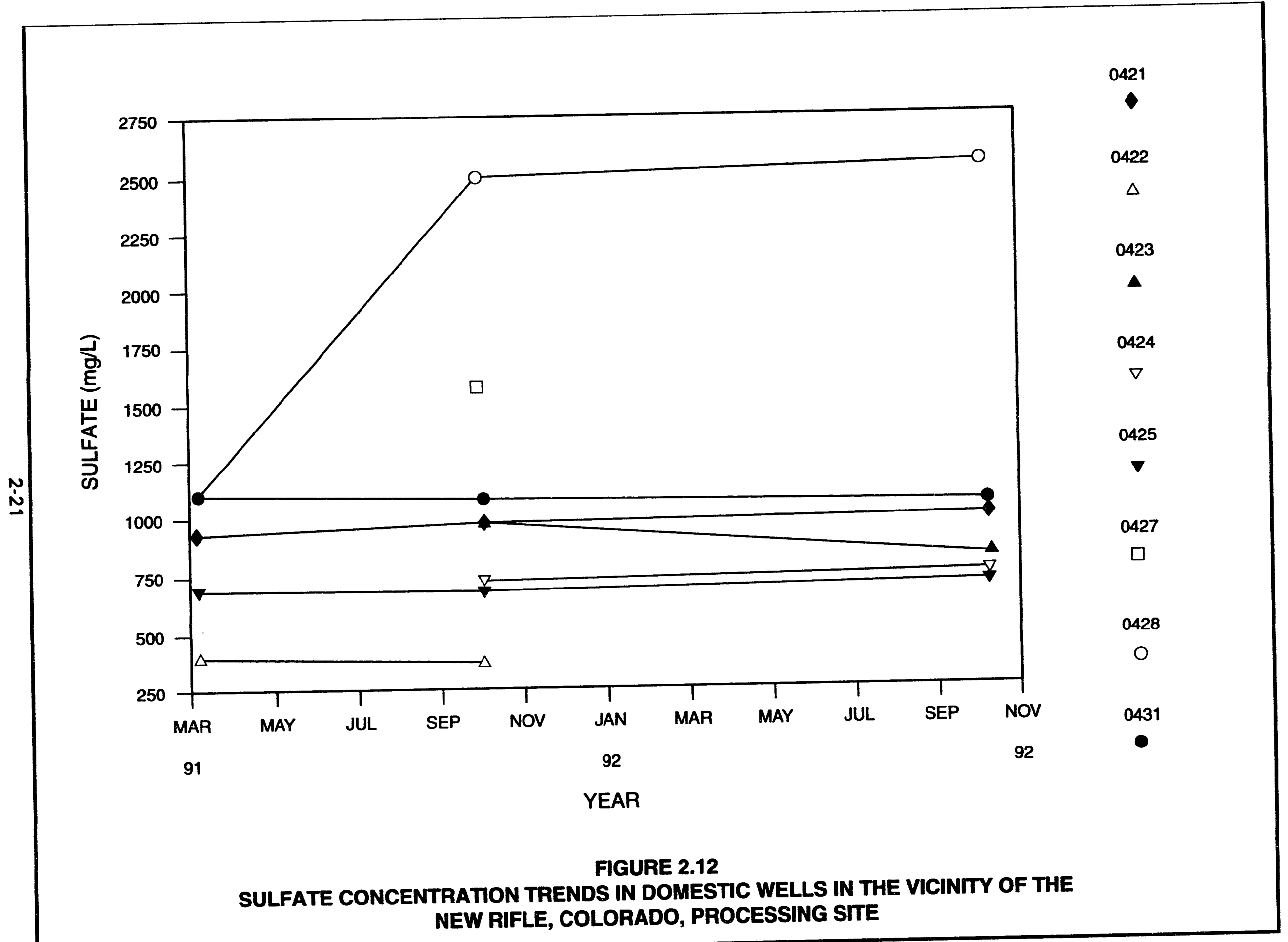


Figure 2.13 shows results of unfiltered (total) uranium analyses over the past 4 years for New Rifle vicinity domestic wells. Figures 2.14 and 2.15 show unfiltered sulfate and uranium concentration trends for downgradient domestic well RFN-0428. Filtered and unfiltered data have provided similar results for samples collected near the Rifle sites.

The uranium unfiltered (total) concentrations observed in well RFN-0428 are higher than those in all domestic wells located north of the New Rifle processing site. The uranium concentrations in RFN-0428 appear to be significantly above the upper range at which natural uranium occurs in background ground water in the vicinity of the Rifle sites.

Sulfate concentrations in well RFN-0603, which has been affected by migrating tailings seepage, have historically ranged from 550 to $2820 \mathrm{mg} / \mathrm{L}$. Figure 2.14 shows that sulfate concentrations in ground water from domestic well RFN-0428 fluctuate within a range typical of concentrations observed in DOE Well RFN-0603.

Unfiltered uranium data from RFN-0428 (Figure 2.15) show a fairly steady increase in concentration since early 1991, when sampling of the well began. The range in uranium concentrations (approximately 0.046 to $0.073 \mathrm{mg} / \mathrm{L}$ ) is within the historical range of uranium concentration $(0.023$ to $0.128 \mathrm{mg} / \mathrm{L})$ detected in RFN-0603 and is probably above the range of uranium concentrations known to exist in background ground water in the vicinity of the Rifle processing sites.

\subsection{DATA COLLECTION OBJECTIVES}

Data collection objectives (DCO) identify the reasons for collecting data. These include regulatory requirements, compliance monitoring, site characterization, risk assessment, and other considerations.

Data quality objectives (DOO) define the manner in which samples are collected, handled, and analyzed. DQOs define analytical support levels; establish standard procedures for water sampling, preservation, transport, and various other field procedures; ensure that procedures follow quality assurance (QA) and quality control $(\mathrm{OC})$ protocols; and provide analytical data validation. DOOs to be followed during data collection and evaluation activities are stated in a guidance document for water sampling and analysis plans (DOE, 1993), a QA implementation plan (QAIP) (DOE, 1994), and applicable SOPs (JEG, n.d.).

\subsubsection{Regulatory requirements}

The regulatory requirements for ground water and surface water sampling at the Rifle sites are specified in 40 CFR Part 192 (1994) and in state of Colorado regulations. 


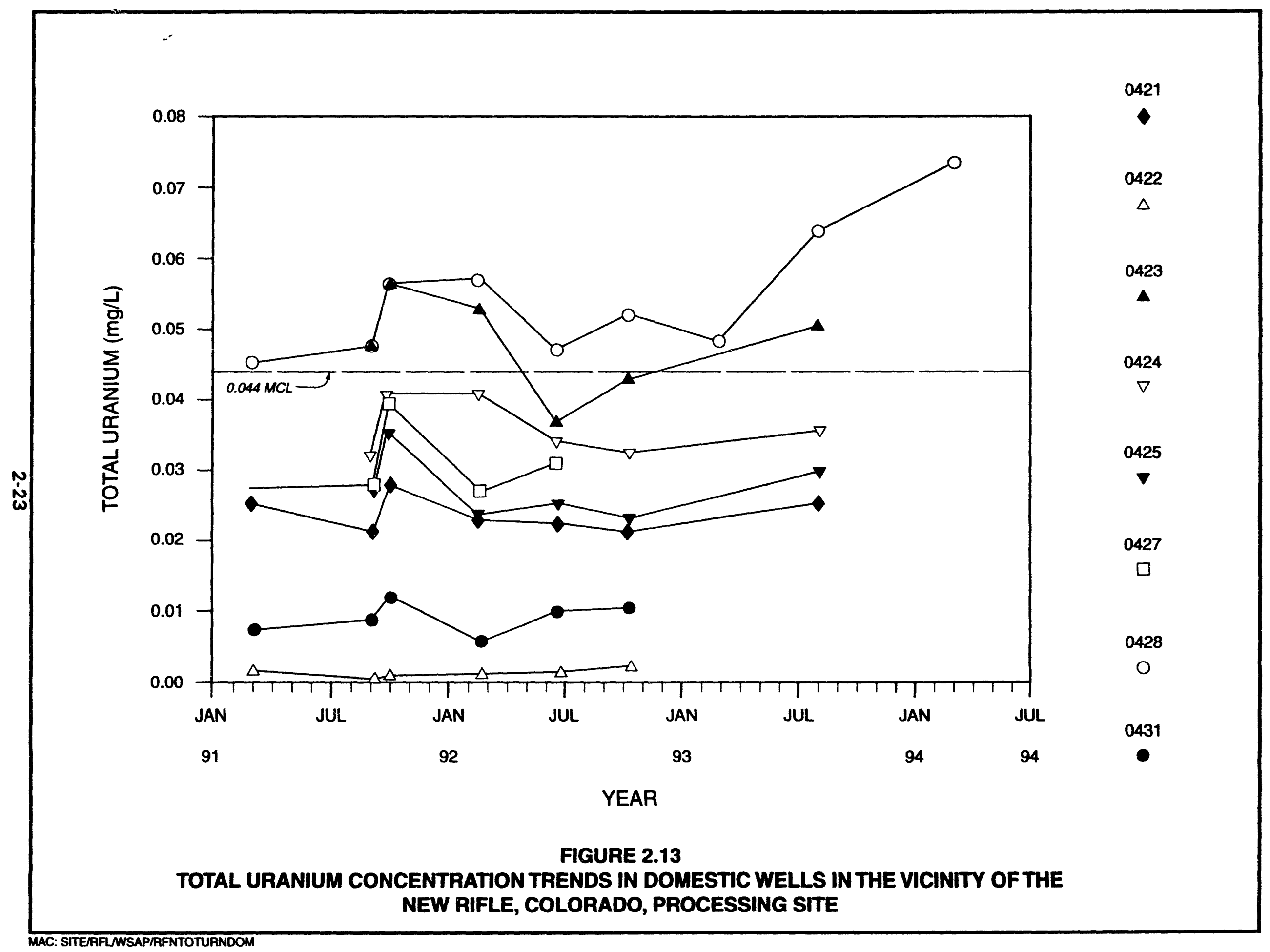




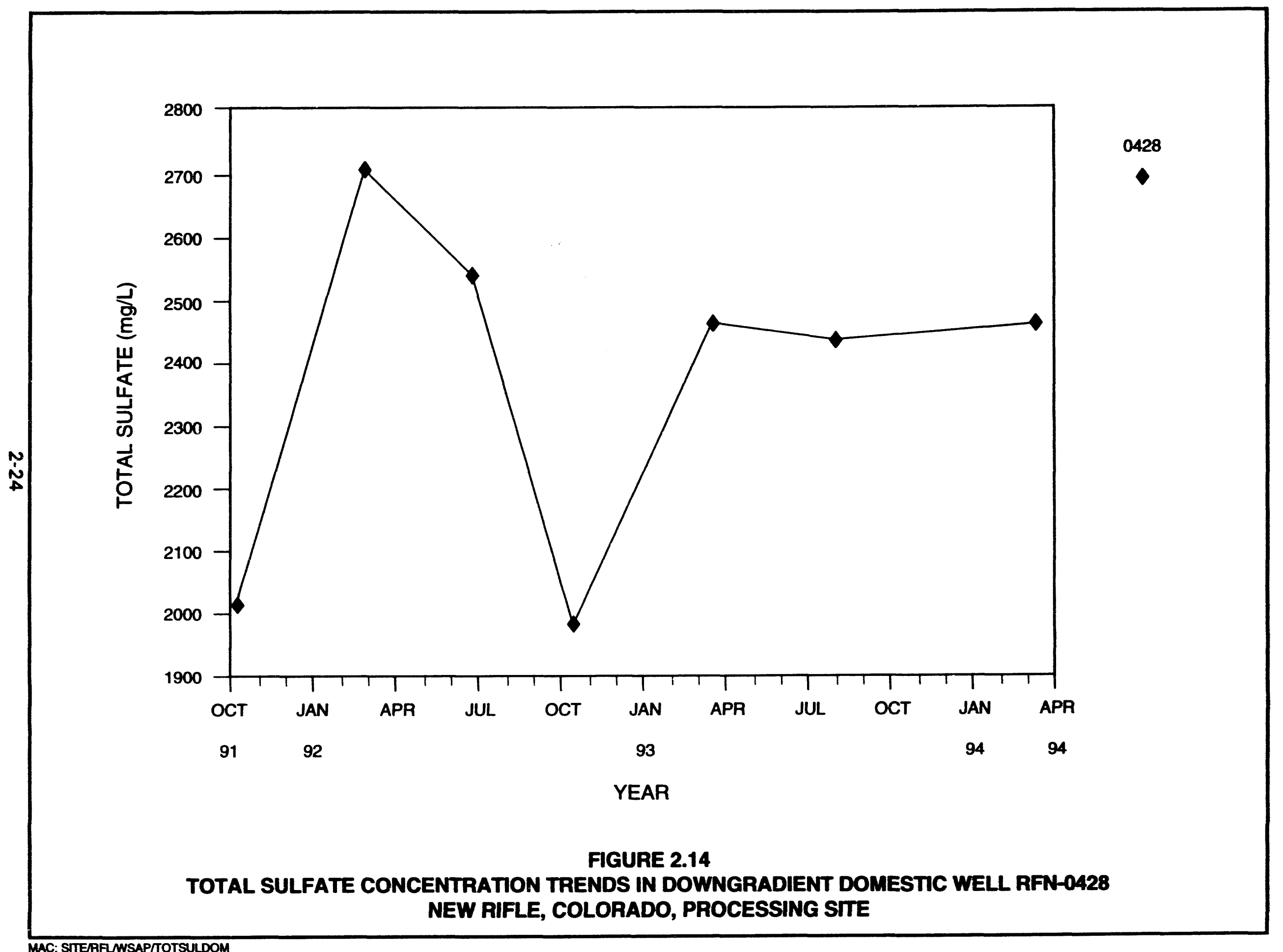




\subsubsection{Compllance menitoring}

Surface remedial action started in 1992 and is scheduled for completion in 1995. Ground water compliance monitoring is required during construction (DOE, 1992).

\subsubsection{Site characterization}

Previous characterization activities have indicated that the portion of the uranium plume in which concentrations are at or above the $M C L$ in the alluvial aquifer at New Rifle extends a minimum of approximately $5000 \mathrm{ft}(1524 \mathrm{~m})$ west. The uranium plume in the alluvial aquifer at Old Rifle extends a much shorter distance downgradient of the pile. Uranium concentrations above MCLs have also been detected in the Wasatch Formation. However, due to the less transmissive hydraulic characteristics of the Wasatch Formation, the contamination is not moving at an appreciable rate within this formation at either site. DOE monitor wells, local private wells, springs, and surface water ponds will continue to be sampled to determine changes in the extent and level of contamination.

\subsubsection{Bisk assessment}

Data are currently being gathered for the Rifle baseline risk assessment. This risk assessment is scheduled to be completed in 1995.

Water samples for risk assessment will be taken from monitor wells and surface water locations at and near the Old and New Rifle processing sites. Results from the sampling will be used to determine contaminant plume locations, constituent concentrations, and water quality and quantity at potential receptor points. Unfiltered samples along with filtered sample information are generally required to assess risk.

To accurately assess the risks associated with past uranium processing activities, the background ground water quality and the extent of contamination in the alluvial aquifer must be determined. Three shallow well points were installed in March 1994 to help assess risk. Wells RFO-0605 and RFO-0606 were installed in the alluvium upgradient of the Old Rifle site to more clearly establish background ground water quality. Well RFN-0620 was installed downgradient of the New Rifle site to more clearly estimate the maximum extent of contamination in the alluvium. These well point locations are shown in Figures 2.1 and 2.2. Initial sampling results from these wells are being evaluated.

\subsection{WATER SAMPLING PLAN}

Water quality sampling is being conducted at the processing site to 1) support the baseline risk assessment, 2) monitor for ground water compliance during remedial action construction, and 3) define the extent of contamination. 
Sampling locations, constituent selection, and sampling frequency are discussed in Sections 2.3.1, 2.3.2 and 2.3.3. Interpretation and evaluation of analytical data are discussed in Sections 2.3.4 and 2.3.5.

\subsubsection{Samoling locations}

A description of and rationale for recommended DOE and domestic sampling locations and sampling frequencies are provided in Table 2.3 for Old Rifle and Table 2.4 for New Rifle. A total of 11 DOE Old Rifle and 18 DOE New Rifle monitor wells will be sampled (Figures 2.2 and 2.3). If a limited quantity of water is available, sample collection bottles will be prioritized (from highest priority to lowest) as follows: metals, anions, gross alpha, and radium-226 and radium-228.

Thirteen private wells near the Rifle processing sites will be sampled. Figure 2.11 shows the locations of private wells. Unfiltered and filtered samples will be collected from monitor well RFN-0428 and unfiltered samples will be collected for the remaining domestic wells. When possible, domestic samples will be collected from a drinking water outlet downgradient of any private filtering system.

Four surface water samples will be collected near the former processing sites: RFO-0572, located directly downgradient of the Old Rifle processing site; RFO-0570, from One-Mile Pond, located approximately $5000 \mathrm{ft}(1524 \mathrm{~m})$ northeast of (upgradient from) Old Rifle; RFO-0573, from the seep located near One-Mile Pond; and RFN-0575, located downgradient from the Roaring Fork gravel pit. The rationale for sampling these locations is included in Tables 2.3 and 2.4 .

\subsubsection{Constituent selection}

The ground water monitoring program includes collecting and analyzing ground water samples from the monitor wells listed in Tables 2.3 and 2.4 and discussed in Section 2.3.1. Ground water samples initially were evaluated for hazardous constituents generally expected to be in or derived from the residual radioactive material related to the uranium processing activities. The list of constituents analyzed during screening monitoring to determine background and baseline ground water quality has been modified during subsequent sampling events to reflect only hazardous constituents related to uranium processing activities at this site.

Based on existing water quality data, the following constituents will be monitored at the Rifle processing sites in 1994 (constituents monitored at the Rifle sites will be similar, except cadmium and nitrate will be excluded at Old 


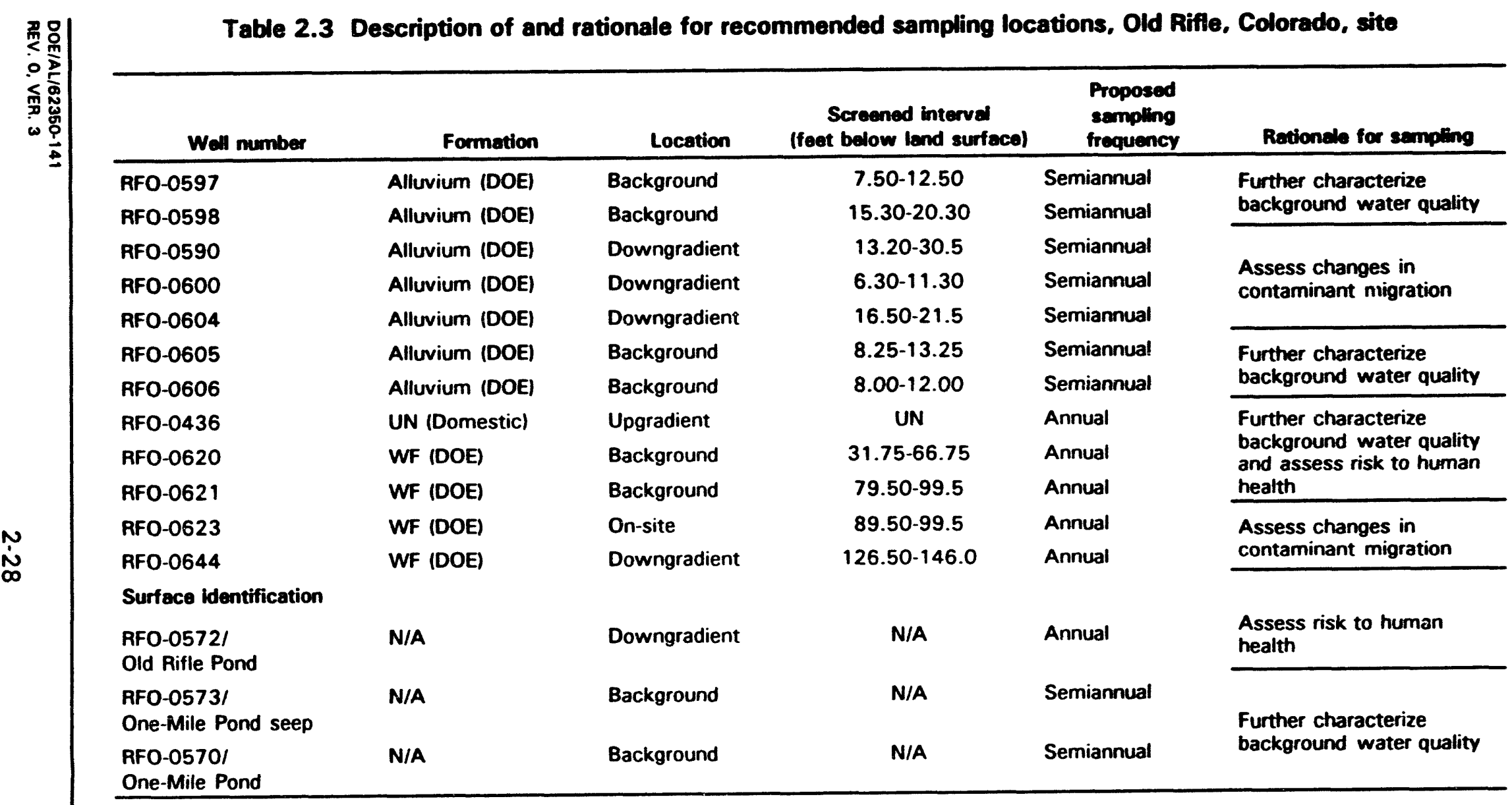

WF - Wasatch Formation.

UN - Unknown.

N/A - Not applicable. 


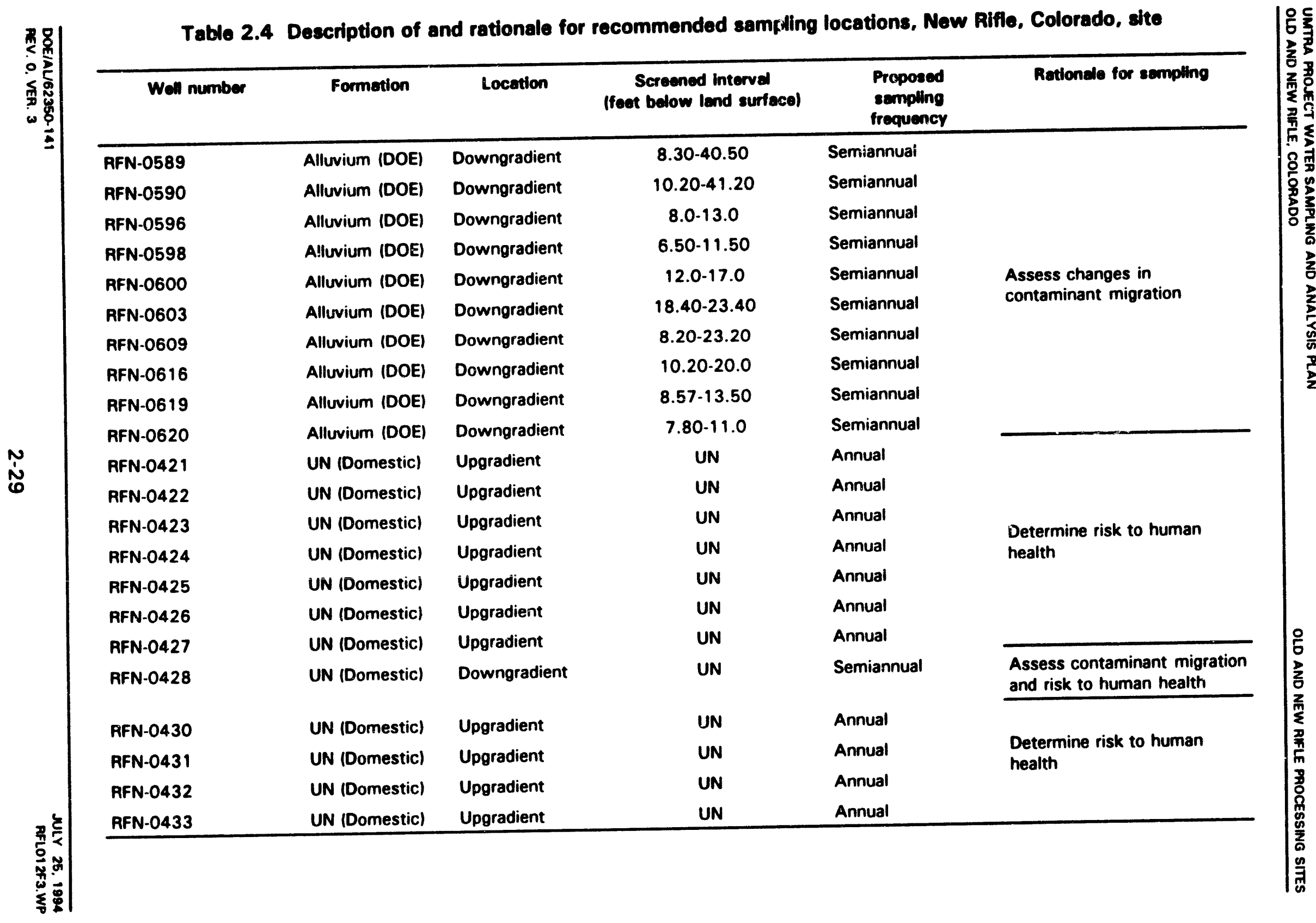




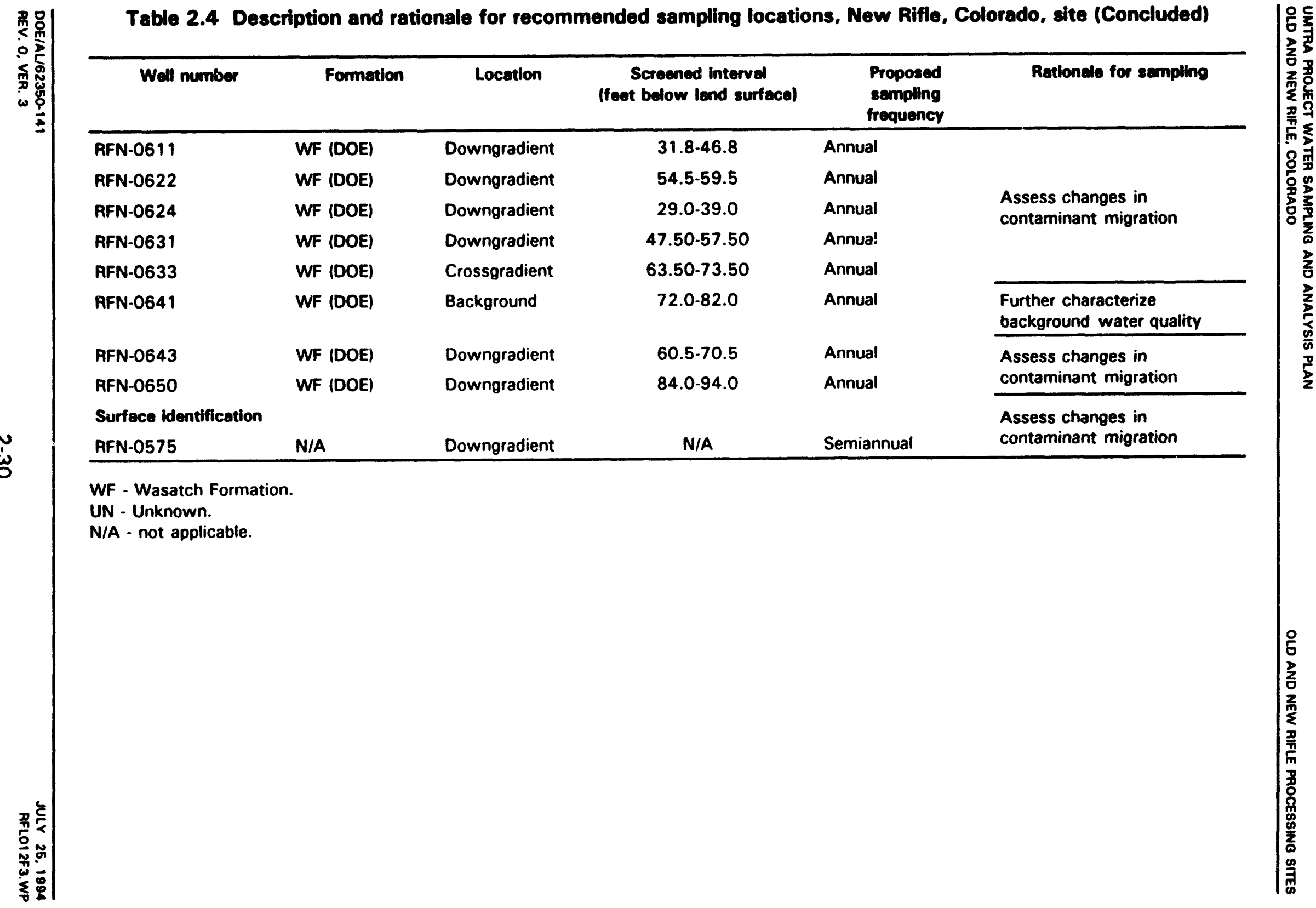


Rifle; antimony, fluoride, lead, lead-210, and thorium-230 have been added for the baseline risk assessment):

- Field parameters - alkalinity, dissolved oxygen, oxidation/reduction potential, $\mathrm{pH}$, specific conductivity, and temperature.

- Laboratory analyses-ammonium, antimony, arsenic, barium, cadmium, calcium, chloride, chromium, fluoride, gross alpha, iron, lead, lead-210, magnesium, manganese, molybdenum, nitrate, potassium, radium-226, radium-228, selenium, sodium, sulfate, TDS, thorium-230, TOC, uranium, vanadium, and zinc.

The majority of the above parameters will be monitored because they have been found to be related to uranium processing activities. Additional constituents to be monitored for hydrogeochemical site characterization include calcium, chloride, magnesium, potassium, sodium, and TDS.

\subsubsection{Sampling frequency}

Ground water has been monitored at the Rifle processing sites since 1983 to establish background and baseline ground water quality before and during remedial action activities. The past sampling frequency has allowed seasonal variations in ground water quality to be detected.

Tables 2.3 and 2.4 list wells to be sampled in 1994, their proposed sampling frequencies, and the rationale for these frequencies. These sampling frequencies permit trends in ground water flow conditions and quality to be evaluated. They also provide additional information and continuity to the data base that could be useful during the UMTRA Project's ground water remediation phase.

\subsubsection{Data interpretation}

Water sampling data collected during 1994 will be analyzed and evaluated according to prescribed UMTRA Project procedures and compared with the existing data base. Trend analyses will be performed to detect any variations in ground water flow conditions and ground water quality. Variations will be evaluated and modifications to the sampling plan will be noted, justified, and implemented, as appropriate.

Long-term sampling frequency and parameters will be considered, taking into consideration the following factors:

- Trends in uranium and sulfate concentrations over time-was the elevation in concentration a one-time occurrence or part of a statistical trend?

- Spatial changes in uranium and sulfate concentrations. 
- Changes in uranium concentrations relative to changes in concentrations of other parameters - are elevated uranium and sulfate concentrations associated with changes in other water quality parameters?

- Source term behavior-do the mineralogy of subsurface soils, solubility of the hazardous constituents of concern, and ground water velocity suggest that source term concentrations are likely to increase or decrease with time?

Water quality and water level data will be reviewed during the data validation process and the results will be summarized in an annual site environmental report (ASER). Notable trends and variations in water levels and water quality will be included in the report. Seasonal fluctuations can be taken into account in trend evaluations. Conformance with or deviations from the conceptual model of the hydrogeologic and geochemical environment at and near the Rifle processing sites will also be discussed and updated in the ASER. These results will continue to be sent to the Colorado Department of Health as the validated data become available throughout each year.

\subsubsection{Anomalous data evaluation}

All water quality data will be subject to rigorous data validation and QA/QC procedures outlined in UMTRA Project SOP 16.3.2. This procedure provides the criteria for systematically evaluating the results of radiochemical and general inorganic chemical analyses and documenting the evaluation.

If results from water sampling are beyond the range of expected values, the suspect data will be evaluated to determine the cause of the deviation. If the deviation cannot be related to an error in sample collection or analysis or to processes reasonably expected to occur in the hydrogeologic environment, the location will be resampled during the next scheduled sampling round, or sooner if dictated by an urgent need related to potential impact to human health and the environment. 


\subsection{ESTES GULCH DISPOSAL SITE}

\subsection{SITE CONCEPTUAL MODEL}

The site conceptual model is based on available hydrogeologic information, site reconnaissance, and data from monitor wells installed in the Wasatch Formation. The site conceptual model is summarized below.

\subsubsection{Physiographic setting}

The Estes Gulch disposal site is approximately $6 \mathrm{mi}(9.6 \mathrm{~km})$ north of Rifle (Figure 1.1). The site is between the Grand Hogback to the northeast and State Highway 13 to the south. The site terrain slopes gently upward to the north toward the Grand Hogback. The site is on federal land administered by the Bureau of Land Management.

\subsubsection{Geology}

The Estes Gulch disposal site is on the southwestern flank of the Grand Hogback monocline. The Wasatch Formation underlies the site and consists of at least $3800 \mathrm{ft}(1158 \mathrm{~m})$ of variegated claystones, siltstones, shales, and finegrained sandstones. The Mesaverde Group (Ohio Creek and Williams Fork Formations [uppermost aquifer]) underlies the Wasatch Formation. The Williams Fork Formation of the Mesaverde Group is approximately $4500 \mathrm{ft}(1372 \mathrm{~m})$ thick and consists of light-brown to white sandstones, gray to black shale, and coal beds (Tweto, 1979). The massive resistant sandstone beds of this formation make up the Grand Hogback north of the disposal site. The thin Ohio Creek Formation is considered by some authors to be the uppermost unit of the Mesaverde Group (and Williams Fork Formation). However, the kaolinitic conglomeratic Ohio Creek unit is probably less than $50 \mathrm{ft}(15 \mathrm{~m})$ thick near Estes Gulch and is not known to be a regional aquifer in the area.

Beneath the site, the Wasatch Formation dips approximately 65 to 75 degrees to the southwest. This dip decreases abruptly to 10 to 20 degrees about 500 to $800 \mathrm{ft}(152$ to $244 \mathrm{~m})$ downslope of the toe of the disposal cell. This abrupt change in dip occurs along a fault that parallels the Grand Hogback. The fault is filled with clay gouge and does not appear to be a significant ground water transport pathway.

\subsubsection{Hydrology}

Limited ground water occurs locally in the Wasatch Formation aquitard at Estes Gulch. Localized zones of more permeable fracture zones or sandstone lenses containing water are found at depths ranging from 150 to $467 \mathrm{ft}$ (46 to $142 \mathrm{~m}$ ). 
Ground water in the Williams Fork Formation is confined and flow is structurally controlled. Ground water flows downdip to the southwest, away from the Grand Hogback toward the axis of the Piceance Creek Basin.

The average hydraulic conductivity of the upper weathered Wasatch Formation bedrock at Estes Gulch is in the range of $10^{-7} \mathrm{~cm} / \mathrm{s}$, while the deeper nonweathered Wasatch Formation has a hydraulic conductivity in the range of $10^{-8} \mathrm{~cm} / \mathrm{s}$. The hydraulic conductivity of the Williams Fork Formation is probably greater than that of the Wasatch Formation.

\subsubsection{Water quality}

Background ground water quality in the Wasatch Formation beneath the Estes Gulch site is classified as Class III (limited use). Water quality from several monitor wells at the disposal site had a TDS content ranging from 8,260 to $25,100 \mathrm{mg} / \mathrm{L}$. Because of its poor quality, ground water beneath the Estes Gulch disposal site has relatively low value and is not likely to be used in the future. Regional ground water quality in the Mesaverde Group is good, with TDS ranging from 41 to $235 \mathrm{mg} / \mathrm{L}$ (Gile et al., 1981). Ground water in formations of the Mesaverde Group is too deep to be used cost-effectively for domestic or stock watering purposes.

The Wasatch Formation aquitard beneath the Estes Gulch disposal cell is projected to be more than $3800 \mathrm{ft}(1158 \mathrm{~m})$ thick. Therefore, the disposal cell is geologically isolated from the uppermost aquifer.

\subsection{DATA COLLECTION OBJECTIVES}

As stated in Section 2.2, DCOs identify the reasons for collecting data. These include regulatory requirements, compliance monitoring, site characterization, risk assessment, and other considerations.

DOOs define the manner in which samples are collected, handled, and analyzed. DQOs define analytical support levels; follow standard procedures for water sampling, preservation, transport, and various other field procedures; ensure procedures follow $\mathrm{QA}$ and $\mathrm{QC}$ protocols; and provide analytical data validation. DQOs to be followed during data collection and evaluation activities are stated in a guidance document for water sampling and analysis plans (DOE, 1993), a. QAIP (DOE, 1994), and applicable SOPs (JEG, n.d.).

\subsubsection{Regulatory requirements}

The regulatory requirements for ground water and surface water sampling at the Estes Gulch disposal site are specified in 40 CFR Part 192 (1994) and in state of Colorado regulations. 


\subsubsection{Comoliance monitoring}

Post-closure monitoring of ground water in the uppermost aquifer (Williams Fork Formation) is not proposed because of the Class III designation of ground water in the Wasatch Formation and because of the considerable thickness of the Wasatch Formation (projected to be approximately $3800 \mathrm{ft}[1158 \mathrm{~m}]$ ).

Ground water in the Wasatch Formation beneath the Estes Gulch disposal site is Class III (limited use) (40 CFR \$192.11(e)(1)) (1994). Limited use ground water is ground water that is not a current or potential source of drinking water because 1 ) the concentration of TDS exceeds $10,000 \mathrm{mg} / \mathrm{L} ; 2$ ) widespread ambient contamination unrelated to activities involving processing activities exists, and the contamination cannot be cleaned up using treatment methods reasonably employed in public water supply systems, or 3) the quantity of water available is less than 150 gallons per day.

\subsection{WATER SAMPLING PLAN}

No sampling plan is iequired for compliance monitoring of the uppermost aquifer at the Estes Gulch disposal cell for the reasons stated in Section 3.2.2. 


\subsection{LIST OF CONTRIBUTORS}

The following individuals contributed to the preparation of the WSAP.

\begin{tabular}{ll}
\hline Name & Contribution \\
\hline T. Monks & Overall document responsibility, authorship \\
S. Cox & Site management, document review \\
J. Blount, M. Day, A. Holm & Document review \\
D. Thalley & Technical editing \\
L. Keith, D. Minchow & Text processing \\
T. Gagliano, B. Harvey & Graphic design \\
\hline
\end{tabular}




\subsection{REFERENCES}

Gile et al. (L.H. Gile, T. W. Hawley, and R. B. Grossman), 1981. Soils and Geomorphology in the Basin and Range Area of Southern New Mexico-Guidebook to the Desert Project, New Mexico Bureau of Mines and Mineral Resources, Memoir 39, Socorro, New Mexico.

DOE (U.S. Department of Energy), 1934. UMTRA Project Technical Assistance Contractor Quality Assurance Implementation Plan, DOE/AL/62350-72D, Rev. O, March 1994, prepared by the U.S. Department of Energy, UMTRA Project Office, Albuquerque Operations Office, Albuquerque, New Mexico.

DOE (U.S. Department of Energy), 1993. Guidance Document for Preparing Water Sampling and Analysis Plans for UMTRA Sites, DOE/AL/62350-70F, prepared by the U.S. Department of Energy, UMTRA Project Office, Albuquerque Operations Office, Albuquerque, New Mexico.

DOE (U.S. Department of Energy). 1992. Guidance for Implementing the UMTRA Project Long-term Surveillance Program, UMTRA-DOE/AL-350125.0000, prepared by the U.S. Department of Energy, UMTRA Project Office, Albuquerque Operations Office, Albuquerque, New Mexico.

DOE (U.S. Department of Energy), 1991. Remedial Action Plan and Site Design for Stabilization of the Inactive Uranium Mill Tailings Sites at Rifle, Colorado, UMTRA-DOE/AL-050506.0000, final, prepared by the U.S. Department of Energy, UMTRA Project Office, Albuquerque Operations Office, Albuquerque, New Mexico.

DOE (U.S. Department of Energy), 1989. Technical Approach Document, UMTRADOE/AL-050425.0002, prepared by the U.S. Department of Energy, DOE UMTRA Project Office, Albuquerque Operations Office, Albuquerque, New Mexico, p. 303.

FBDU (Ford, Bacon \& Davis Utah, Inc.), 1977. Phase II - Tit/e I Engineering Assessment of Inactive Uranium Mill Tailings, New and Old Rifle Sites, Rifle, Colorado, report prepared by FBDU, Salt Lake City, Utah, for the U.S. Department of Energy, UMTRA Project Office, Albuquerque Operations Office, Albuquerque, New Mexico.

JEG (Jacobs Engineering Group Inc.), n.d. Albuquerque Operations Manual, standard operating procedures, prepared by Jacobs Engineering Group Inc., Albuquerque, New Mexico, for the U.S. Department of Energy, UMTRA Project Office, Albuquerque Operations Office, Albuquerque, New Mexico.

Tweto, O., 1979. "Geologic Map of Colorado," U.S. Geological Survey, in cooperation with the Geological Survey of Colorado, scale 1:500,000, Washington, D.C. 


\section{CODE OF FEDERAL REGULATIONS}

40 CFR Part 192, Health and Environmental Protection Standards for Uranium and Thorium Mill Tailings, U.S. Environmental Protection Agency (1994).

\section{FEDERAL REGISTER}

52 FR 36000, "Standards for Remedial Actions at Inactive Uranium Processing Sites; Proposed Rule," September 24, 1987. 

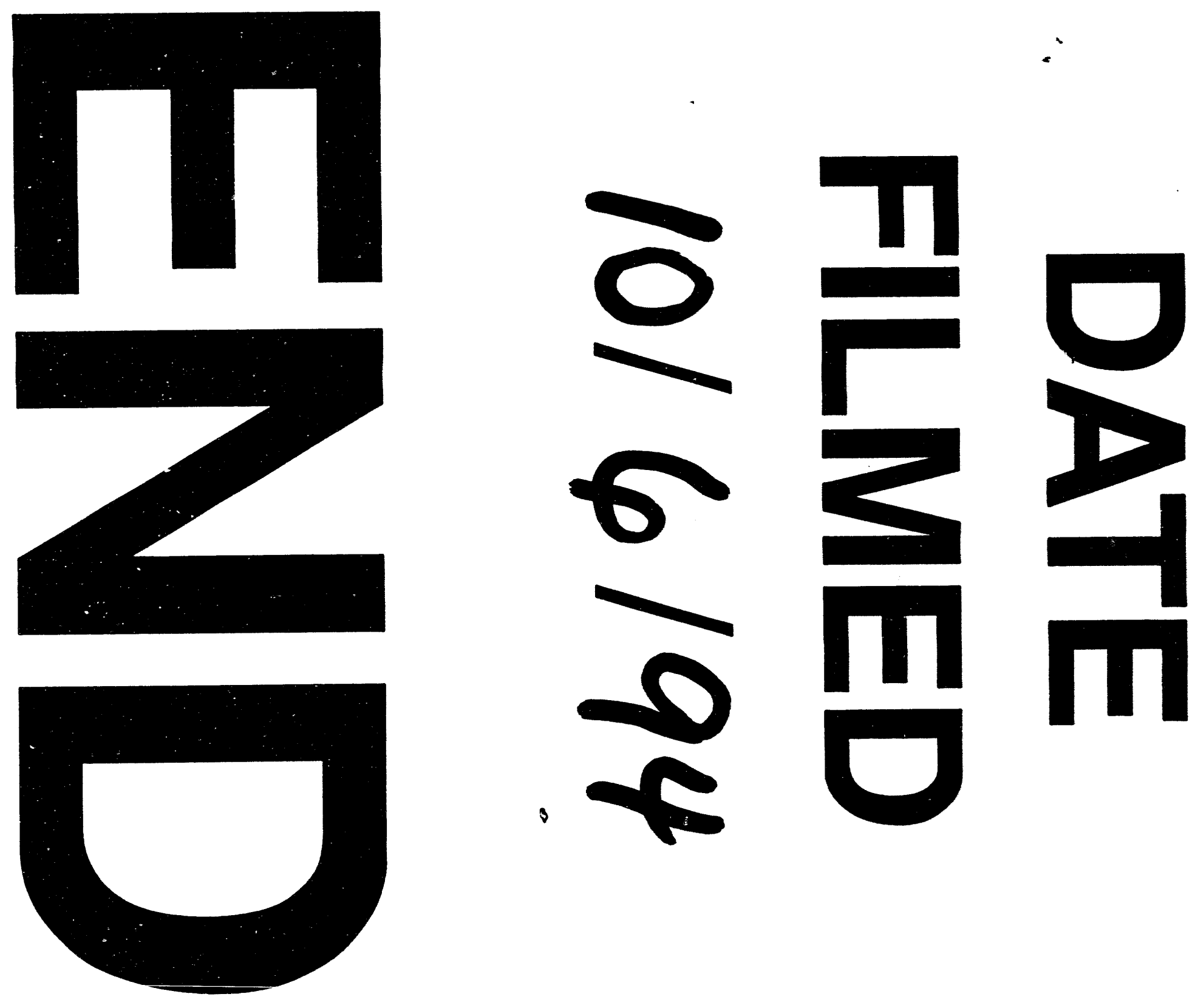


$$
\text { L }
$$

